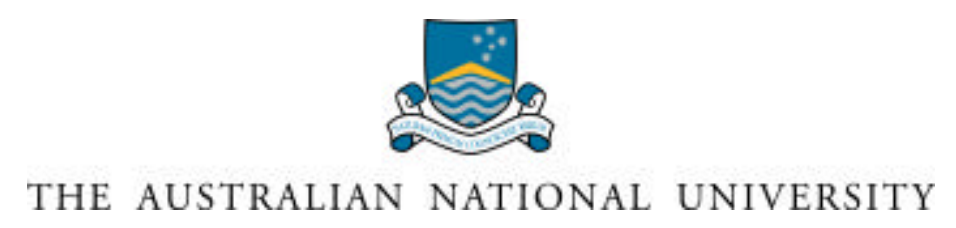

Working Paper Series in Finance 99-04

\title{
THE EXPLANATORY POWER OF POLITICAL RISK IN EMERGING MARKETS
}

\author{
C.M. Bilson, T.J. Brailsford and V.J. Hooper \\ School of Finance and Applied Statistics \\ Australian National University
}

JEL Classification

Keywords

Last revision date:

Contact author:
F21, F30, G15

Emerging Stock Markets; Political Risk;

International Asset Pricing

March 2001

Chris Bilson

School of Finance and Applied Statistics

The Australian National University

Canberra ACT 0200 AUSTRALIA

Telephone: 0261254867 (International +61 26125 5005)

Facsimile: 0261254867 (International +61 26125 5005)

Email: chris.bilson@anu.edu.au

The working paper series is for manuscripts in draft form. Comments are welcome and should be sent to the contact author. Please do not quote without permission.

(C) Copyright 1999 Bilson, Brailsford and Hooper 


\title{
THE EXPLANATORY POWER OF POLITICAL RISK IN EMERGING MARKETS
}

\author{
by \\ C.M. Bilson, T.J. Brailsford and V.J. Hooper \\ School of Finance and Applied Statistics \\ Australian National University \\ Canberra 0200
}

AUSTRALIA

\begin{abstract}
There is substantial argument that political risk is an important and increasing influence on international portfolio allocation decisions. The purpose of this paper is to investigate the relation between political risk and stock returns within the context of emerging markets. The issue is examined using a framework that controls for global and other local return influences. Consistent with the paper's predictions, the findings reveals that political risk is more important in explaining return variation in emerging markets, particularly in the Pacific-Basin, than in a comparative sample of developed markets. At an aggregate level, supportive evidence is found of a positive relation between political risk and ex-post returns in emerging markets that is robust to alternative risk measures, and more prevalent during the 1990s.
\end{abstract}

\section{Acknowledgments}

The authors thank the following for the constructive comments on earlier drafts - an anonymous referee, Frank Finn, Richard Heaney, Barry Oliver, and delegates at the 1999 Asia-Pacific Finance Conference (Melbourne). Financial support was provided through the Australian Research Council Grants Scheme. 


\section{Introduction}

The purpose of this study is to test for an association between political risk and emerging stock market returns. The globalisation and integration of capital markets has opened up new investment opportunities for international investors. As such, political risk has become an increasingly important concern when making international portfolio allocation decisions. As emerging stock markets tend to be located in developing countries, which are prone to periods of political instability (Diamonte et al. 1996), they provide a useful setting for an examination of the relation between political risk and stock market returns.

Political risk can encompass many factors and events such as blocked funds, repatriation constraints in the form of exchange controls, expropriation or nationalisation of property and resources, inconvertibility of currency, war damage, civil strife, actions against personnel (eg. kidnapping), limits on remittances, government interferences with contractual terms, discriminatory taxation, politically-based regulations on operations and the loss of copyright protection (Howell and Chaddick 1994).

Jodice (1985) defines political risk as:

"Changes in the operating conditions of foreign enterprises that arise out of a political process, either directly through war, insurrection, or political violence, or through changes in government policies that affect the ownership and behaviour of the firm. Political risk can be conceptualised as events in the national and international environments that can affect the physical assets, personnel, and operations of foreign firms." (Jodice 1985)

Jodice's definition places emphasis upon the impact that an event has upon a firm's operating conditions rather than the actual event itself. Other definitions include the "propensity to expropriate" (Truit 1974), "exchange controls" (Aliber 1973) or "adverse changes stemming from radical political changes" (Green 1974). Prast and Lax (1982) argue that "in the generic sense, political risk is the probability that the goals of the project will be affected by changes in the political environment". Robock (1971) distinguishes between 'macro risk' and 'micro risk'. Macro risk includes variables that effect foreign direct investment from a global perspective, such as exchange controls. Micro risks are generally industry-specific or projectspecific, such as unexpected taxes.

Cherian and Perotti (1999) focus on policy changes, and more specifically the opportunistic policy maker, in their discussion of political risk. They include the following under the umbrella of political risk - inconsistent taxation and legal systems, capital expropriation and nationalisation policies, imposition of foreign exchange and capital controls and the institution of tariffs and barriers. Perotti (1995) argues that political risk can only be reduced through demonstrated and sustained policy reform. The mere announcement of a policy change is 
insufficient and governments only gain credibility when policy changes are actually implemented. In Perotti and van Oijen (1999), it is argued that privatization programs force the creation of "rules of the game" for security markets and assist in the development of an explicit regulatory framework, thereby reducing political risk.

In summary, the concept of political risk is broad and encompasses many facets. However, it might be generally described as that risk which arises from the potential actions of governments and other influential domestic forces which threaten expected returns on investment.

The above discussion highlights that factors associated with political risk are typically qualitative in nature. However, testing the impact of such factors on return variation requires a quantitative measure. In this paper, quantitative political risk data, sourced from Political Risk Services Inc., are employed. These data derive from a risk rating system that measures political, economic and financial risks. The same data have been used previously by Erb et al. (1996), and they document a relation between stock market returns and financial, economic and political risk. This paper's approach differs to that of Erb et al. in a number of ways. First, the paper explores the power of political risk indices in explaining returns in relation to a world market proxy. The empirical tests uncover whether political risk provides any further information over that already impounded in the world market portfolio whereas Erb et al. consider only the relation between returns and political risk. Second, the use of monthly observations on both the risk and return variables gives rise to a larger data set. ${ }^{1}$ Third, the paper employs contemporaneous observations between the return and political risk series which allows for an immediate consideration of the impact of changes in analysts' forecasts. ${ }^{2}$ Fourth, the impact of political risk is considered at the country level rather than an aggregated portfolio approach. A test for the specification of a pooled cross-sectional time series model is also conducted in order to determine whether a relation between stock market returns and risk indices exist at an aggregate level.

The remainder of the paper is organised as follows. The next section considers the nature of emerging markets. Section three discusses the models employed in the paper. Section four presents a description of the returns and political risk data. Section five presents the results and the final section contains the conclusions.

\footnotetext{
${ }^{1}$ In comparison, Erb et al. (1996) employ half-yearly data for the returns and political risk indices, which results in a reduced sample (ie. approximately 20 observations per country over their 1984 to 1995 period).

${ }^{2}$ The analysts' forecasts are updated on a monthly basis. In comparison, Erb et al. (1996) lag the political risk variable by six months.
} 


\section{Emerging Stock Markets}

The importance of emerging stock markets, from the perspective of the international investor increased with the change in global political dynamics that occurred during the 1980s. The collapse of the Berlin Wall symbolised the fall of Communism and the resurrection of a social market economy for many Eastern European countries and the former Soviet Union. Coupled with this, the progressive moves of China and various Asian countries toward a social market orientated economy created a demand for international equity capital. Further, the governments of many South American countries followed the example that the United Kingdom set during the 1980s, by privatising many of their State run utilities. As a result, emerging markets now represent a feasible investment alternative for international investors and the last decade has witnessed massive capital flows in and out of emerging stock markets. ${ }^{3}$

The internationalisation of capital and its flow from developed countries to developing countries has raised an important policy issue from the perspective of developing countries. There is substantial controversy over whether portfolio flows of capital to developing countries increase market volatility and destabilise economies. In response to such beliefs, some countries have implemented directives aimed at limiting the amount of capital inflow into their country. ${ }^{4}$ Such restrictions can be viewed as changes in political risk.

Emerging markets are generally seen as less integrated than developed markets (Bekaert and Harvey 1995). Bekaert (1995) suggests that barriers to integration are either macro-economic or market specific. These barriers add to political risk. Macro-economic barriers relate to poor credit ratings, high and variable inflation, exchange controls, economic policy, liquidity risk and currency risk. Market specific barriers are influenced by the degree to which the market is developed in terms of the presence of international brokers, market size, regulatory and accounting systems. Other factors like the propensity (or perception thereof) for 'insider trading' and degree of information asymmetry may act as further barriers as foreigners believe the market to be stacked against outsiders. Institutional factors may also play a role. Investors may be concerned with the level of automated trading, electronic reporting and settlement procedures. Demirguc-Kunt and Huizinga (1995) argue that harmonisation of (capital gains) taxes are also an important consideration. Bekaert (1995) argues that such factors are more important than any restrictions on foreign ownership, as ownership restrictions can typically be circumvented and are usually non-binding in many markets.

\footnotetext{
${ }^{3}$ To illustrate, in 1999 the International Finance Corporation reported the aggregate market value of emerging stock markets as USD\$2,143 billion.

${ }^{4}$ For example in the wake of the Asian financial crisis that occurred towards the end of 1997 and into 1998, some Asian governments re-imposed restrictions on foreign capital through currency conversion restraints.
} 
Returns and risks in emerging stock markets have generally been found to be higher relative to developed markets ${ }^{5}$ (Errunza 1983; Claessens et al. 1993; Harvey 1995a). Further, emerging markets increase the available opportunity set for international investors to improve the riskreturn trade-off in their portfolios because of the weak correlations between the stock market returns of emerging markets and those in developed economies (Errunza 1977; Divecha et al. 1992). Harvey (1995a) implies that this correlation matrix is time-varying due to the integration over time of emerging markets with world markets and the smoothing of market imperfections.

Bekaert and Harvey (1995) suggest that some emerging markets exhibit time-varying integration by appearing to be more integrated than one might expect based on prior knowledge of investment restrictions. Other markets appear to be segmented even though foreigners have relatively free access to their capital markets. This corroborates the finding by Errunza et al. (1992) that the world's capital market is neither fully integrated nor completely segmented. Moreover, recent evidence by Goetzmann and Jorion (1999) shows that emerging markets may go through several phases of 'emergence' and should never be viewed as static.

In summary, emerging stock markets are different from those in developed economies. The exact nature of these differences is not known nor are the reasons homogeneous, but many factors that have been proposed to relate to the differences also relate to aspects of political risk. As such, emerging markets create a good setting in which to examine the influence of political risk on stock market returns.

\section{Models}

A fundamental assumption in finance is that investors prefer higher expected returns for the same level of risk. Various asset pricing models have been developed, such as the capital asset pricing model (CAPM), that incorporate the concept of risk. Within developed markets, models such as the CAPM (and more specifically its empirical analog the market model) have been tested many times. Evidence surrounding the CAPM has cast doubt on the model's ability to adequately explain cross-sectional variations in returns (Fama and French 1992, 1995). However, the CAPM is arguably still the most widely accepted asset pricing model in both academic and practitioner circles. The model has been extended to international capital

\footnotetext{
${ }^{5}$ Moreover, the returns achievable from emerging stock markets appear more predictable than developed markets and exhibit stronger mean reversion properties with a higher degree of autocorrelation (Harvey 1995a; Bekaert 1995; Bekaert and Harvey 1995). However it is questionable as to whether the high and somewhat predictable returns in emerging markets are transitory in nature as evidenced by the substantial declines in market capitalisation in these markets that occurred during 1997 and 1998. In 1997 the International Finance Corporation Investable (IFCI) index fell 16\%, which was the sharpest one-year decline in the index's history. Similarly, the IFCI Asia Index fell by 57\% (IFC, Emerging Stock Markets Factbook 1997).
} 
asset pricing (ICAPM) (Stulz 1981) and employed as a model of the risk-expected return trade-off within an international context.

This paper does not seek to test the ICAPM nor develop an asset pricing model. Rather, the purpose of the paper is to undertake a test of association between political risk and emerging stock market returns. However, the paper requires a framework in which to conduct the tests. As political risk is most likely to be a local variable in the sense that it impacts on the local component of market returns, the first stage in the analysis involves removal of global influences from the return series. Hence, the primary model used here is based upon the empirical analog to the ICAPM, the International Market Model (IMM). The IMM proposes a single-factor return generating process in which returns in each country are sensitive to movements in a world market index. The IMM can be modelled with the following regression:

$$
R_{i t}=a_{i}+b_{i} R_{w t}+r_{i t}
$$

$\mathrm{R}_{\mathrm{it}}$ is the return for country $i$ at time $t$,

$\mathrm{R}_{\mathrm{wt}}$ is the return on the world index at time $t$,

$r_{\text {it }}$ is the residual local return for country $i$ at time $t$.

In the case of a segmented market, there is a question over the appropriate market index to use in (1). Possibilities that have been proposed include returns on a local or regional market index. However, there are problems with such an approach. First, in a multi-country study, the dependent variable is often the local market index itself. Second, the approach requires an estimate as to the market's degree of integration. Obtaining an integration measure is difficult, particularly as the ex-ante theory in relation to defining integration is still at an early stage (Bracker et al. 1999). Further, most markets are neither completely integrated nor segmented and thus, the selection of the market proxy is compromised. Third, there are other ways in which local factors can be captured, as discussed below.

Under the assumptions of the IMM, country-specific influences should be contained in the residual term $\left(r_{i t}\right)$ from (1). The residual can be viewed as the 'local return' which can be modelled as a function a set of unknown K-local risk factors (including political risk), where each local risk factor $\mathrm{j}$ is specific to country $\mathrm{i}$, viz: ${ }^{6}$

$$
\begin{aligned}
& \mathrm{r}_{\mathrm{it}} \sim \mathrm{fn}_{?} ?{ }^{\mathrm{K}} \text { ? } \mathrm{F}_{\mathrm{ij}}^{\mathrm{L}} \text { ? ? } \\
& \mathrm{F}_{\mathrm{ij}}^{\mathrm{L}} \text { is the realisation of the } \mathrm{j} \text { 'th local factor, pertaining to country } \mathrm{i} .
\end{aligned}
$$

\footnotetext{
${ }^{6}$ The local risk factors are examined separately from the world risk factor, as a precaution against nonorthogonality between the local and world risk factors.
} 
A market that is completely segmented would have no exposure to a world index but would be fully sensitive to local risk factors. Unfortunately, the literature is not sufficiently developed to be definitive in relation to the identification of the local risk factors. This issue becomes increasingly complex when a number of emerging markets are considered. For instance, even if the 'true' local risk factors could be identified for a particular market, these factors would most likely vary from the local risk factors for other emerging markets precisely because they represent local sources of exposure. Moreover, even if a set of common factors could be identified, it is likely that specific market sensitivities to these factors would vary (Bekaert and Harvey 1995).

Nevertheless, the literature can be used to aid in the identification of local risk factors that may play important roles across emerging markets generally. ${ }^{7}$ For instance, Bekaert and Harvey (1995) find dividend yields to be important determinants of local equity market variation in emerging markets, and further argue that dividend yields may proxy for capital market liberalisation. Similar associations between returns and dividend yields have been reported for developed markets [eg. Fama and French (1988); Kothari and Shanken (1992)]. Dividend yields forecast both future dividend changes and future returns when expected returns vary through time. They are often used because permanent changes in costs of capital are more likely to be reflected in dividend yields than in returns. Further, dividend yields exhibit less variability than returns and hence are more likely to represent permanent, rather than transitory, changes (Bekaert and Harvey 2000). Hence, contemporaneous dividend yields are positively related to future returns but shocks to expected returns will be inversely related to current prices.

Research into dividend yields in emerging markets is more limited than in developed markets. Bailey and Chung (1995) identify risk-premia with returns from the Mexican stock market over the 1986 to 1994 period and find that dividend yields were highly correlated with these risk-premia. Harvey (1995b) finds that the explanatory power of various models is improved with the addition of a local dividend yield.

Exchange rate risks may also play an important role in determining local returns. Indeed, within a setting of imperfect purchasing power parity, international asset pricing models should

\footnotetext{
${ }^{7}$ From the investor's perspective, recent evidence from Aggarwal et al. (1999) shows that volatility shocks in emerging markets have been almost solely attributable to local market events.
} 
explicitly cater for exchange rate risk (see Solnik 1974; Adler and Dumas 1983; Dumas and Solnik 1995). Exchange rates will reflect the different level of pricing of assets when these assets are measured in the same currency. As such, deviations from purchasing power parity reflect real risks to investors and therefore should be priced accordingly. The direction of the relation between equity returns and exchange risk is difficult to discern. Harvey (1995b) suggests no ex-ante expectation of the sign, but finds that the significant exposures were predominantly negative in emerging markets. Jorion (1991) argues that the direction of the relation between equity returns and currency risk is dependent upon the industrial structure of the country index constituents. Firms that are large exporters benefit from dollar devaluations and therefore have a positive exposure to the exchange rate factor, while firms that rely on imports will be adversely affected by devaluations of the local currency.

From the above discussion, dividend yields and exchange rates may proxy for local risk factors. However, it is unlikely that these two variables fully capture local risk sources. Many other factors have been considered in the literature. For instance, Bekaert and Harvey (2000) include asset concentration, an integration measure, microstructure effects in addition to broader macroeconomic variables. Henry (2000) includes a series of dummy control variables designed to capture shifts in policy relating to trade liberalization, macroeconomic stabilization, privatization and exchange controls. Importantly, these variables are seen as control variables so that the relation of interest can be examined. Similarly, dividend yields and exchange rates can also be viewed as control variables. However, it is impossible to capture all local risk factors in a multi-country study and avoid model mis-specification.

As a solution, in the spirit of Bekaert and Harvey (1995), a further variable is included in this study, namely local return variance, as a proxy for omitted risk sources. In the completely segmented case, the expected local return for a stock within any market will be a function of its covariance with local risk factors. ${ }^{8}$ But as noted above, these local risk factors are difficult to identify and may differ considerably across markets. Since this study focuses on marketwide returns, the covariance between the individual assets and the local risk factors are aggregated, and the resulting variance terms can be proxied by the local return variance. Therefore, in the model, returns relate to local volatility remaining after removing risk sources arising from return variation on the world portfolio, dividend yields and exchange rates (as per Bekaert and Harvey 2000). Hence, the local return variance acts as a residual control variable that proxies for omitted factors, viz:

\footnotetext{
${ }^{8}$ For example, Bekaert and Harvey (1995) assume that a domestic CAPM operates in each market, in which case the aggregate variance is simply the variance of the local market.
} 
$\mathrm{r}_{\mathrm{it}}=?{ }_{\mathrm{i}}+?{ }_{\mathrm{i}} \mathrm{FX}_{\mathrm{it}}+?{ }_{\mathrm{i}} \mathrm{DY} \mathrm{Y}_{\mathrm{it}} ?+?{ }_{\mathrm{i}}{ }^{?}{ }^{?}{ }_{\mathrm{rit}}+?_{\mathrm{it}}$

$r_{i t}$ is the residual returns from the initial regression (1)

$\mathrm{FX}_{\mathrm{it}}$ is monthly percentage change in the exchange rate for country $\mathrm{i}$ at time $\mathrm{t}$

$\mathrm{DY}_{\mathrm{it}}$ is monthly percentage change in the dividend yield for country $\mathrm{i}$ at time $\mathrm{t}$

$?{ }^{?}{ }_{\text {rit }}$ is the variance of monthly local market returns for country $i$ at time t. ${ }^{9}$

The expression in (3) is then augmented with the political risk variable which is the variable of interest, and the resultant model is the primary focus of interest in the paper, viz:

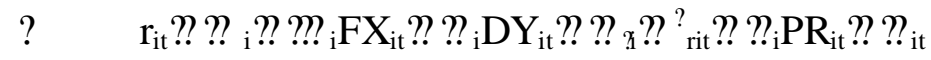

where $\mathrm{PR}_{\mathrm{it}}$ is the monthly change in the political risk index for country $\mathrm{i}$ at time $\mathrm{t}$

Equations (1) and (4) represent the model that is tested in the paper. The variables in (4) are all measured contemporaneously. Implicit in this approach is an assumption that the explanatory variables are available on a timely basis and have an immediate influence over the return series. In the case of the exchange rate, dividend yield and local volatility variables, this assumption follows prior literature and is consistent with the timely incorporation of price information in financial markets. However, there is little existing research available to assess the reasonableness of the assumption with respect to the political risk variable. As noted later in the paper, the construction of the political risk variable incorporates analysts' forecasts. Moreover, the series is updated on a monthly basis. Hence, the contemporaneous specification coincides with the formation of analyst expectations. In this sense, the political risk series is arguably forward looking. To the extent that this assumption is incorrect and a lagged relation is more appropriate, the assumption will bias against finding a significant result.

An issue of concern in the estimation of (4) is possible correlation among the explanatory variables. However, the correlation matrix of the explanatory variables indicates that there is little evidence of multicollinearity. ${ }^{10}$ Specifically, the aggregated average correlations across all markets for each local variable pair are exchange-rate/dividend yield (-0.02), exchange rate/political risk (-0.02), exchange rate/local market volatility (0.05), political risk/dividend yield (0.01), political risk/local market volatility (0.01), and dividend yield/local market

\footnotetext{
9 ? ${ }^{\text {rit }}$ is computed by taking the absolute value of $r_{\text {it }}$ multiplying this value by the square root of (?/2), and then squaring the obtained value (as per Schwert 1990).

${ }^{10}$ Of the 102 correlations (6 correlations for 17 emerging markets), there is only one value that exceeds an absolute value of 0.5 and only five cases where the absolute value exceeds 0.25 .
} 
volatility $(-0.01) .{ }^{11}$ Of note, these average correlations are all close to zero. Further, the use of changes, rather than levels, as in this study, mitigates the potential problem.

The a priori expectation of testing (4) is that investors require additional compensation for bearing political risk over and above the risk encapsulated in the dividend yield, exchange rate and local volatility factors. As above, the exchange rate, dividend yield and local volatility variables can be interpreted as control variables. ${ }^{12}$ Of course, given the nature of political risk, it could also be manifest in the control variables such as the exchange rate factor. If this is the case, then the tests will be biased against finding a result.

\section{Data}

\subsection{Stock returns}

There is no clear definition of what constitutes an emerging stock market. In this study, stock markets are classified as emerging through the listing adopted by the International Finance Corporation (in IFC 'Emerging Market Factbook' 1997). A total of 17 emerging markets are identified ncluding six Latin American countries (Argentina, Brazil, Chile, Colombia, Mexico and Venezuela), seven Asian countries (India, Korea, Malaysia, Pakistan, Philippines, Taiwan and Thailand), one European country (Greece), one Middle Eastern country (Jordan) and two African countries (Nigeria and Zimbabwe).

The paper also studies 18 developed stock markets for comparative purposes (Australia, Austria, Belgium, Canada, Denmark, France, Germany, Hong Kong, Italy, Japan, Netherlands, Norway, Singapore, Spain, Sweden, Switzerland, the UK and the USA). The selection of the developed markets is a trade-off between the availability of data and the desire to maintain roughly equivalent numbers between emerging and developed markets.

The sample period spans January 1984 through December 1997, and hence the earliest month for estimating returns is February 1984. Note that only the last year of the sample is affected by the Asian currency crisis of the late 1990s. Return and political risk data are gathered at the monthly interval for both developed and emerging stock markets. All return data include both dividend and capitalisation adjustments and are expressed in continuously compounded form. In addition, all returns are measured in \$US to negate the influence of the exchange rate and domestic inflation. Hence, returns denominated in this form only retain US inflation but the exchange rate risk may still be present due to purchasing power parity violations.

\footnotetext{
${ }^{11}$ The full correlation matrix is large and hence only the average correlation for each variable pair is reported here. There are four local variables for each of seventeen markets.

${ }^{12}$ For a further discussion of the issue of control variables and political risk see Perotti and van Oijen (1999).
} 
The emerging market return data were obtained from the International Finance Corporation. The return data for the developed stock markets are obtained from Morgan Stanley Capital International (MSCI). Two proxies for the world market index are used - the MSCI World Index and the MSCI USA (country) index.

Table 1 presents descriptive statistics for the return data. Over the sample period, emerging stock markets experienced mean returns roughly similar to those of developed stock markets but exhibited greater return volatility. The average monthly return is $1.2 \%$ for emerging markets and $1.3 \%$ for developed markets. This finding disputes a widely held view in practitioner circles that emerging market returns have been substantially higher than developed market returns. ${ }^{13}$ The average monthly standard deviation of returns of emerging markets $(11.3 \%)$ is almost double that of the developed markets $(6.3 \%)$. The increased volatility present within emerging market returns is also evident by hrger range in the minimum and maximum monthly returns.

Returns from both emerging and developed markets are significantly non-normal. The JarqueBera test provides evidence to reject the hypothesis of normality in fifteen emerging markets and sixteen developed markets. The return series predominantly feature negative skewness and are leptokurtic.

$* * * * * * * * * * * * * * * * * * * * * * * * * * * * * * *$

Table 1 about here

$* * * * * * * * * * * * * * * * * * * * * * * * * * * * * * *$

Table 2 shows the correlation matrix for both the emerging and developed market stock returns. The table contains evidence to support the proposition that emerging market returns have low correlations with developed markets. The average correlation between emerging and developed returns over the period is only $14 \%$. This finding is consistent with previous research that significant diversification benefits appear to exist from the inclusion of emerging market assets in an international portfolio (Divecha et al. 1992). Table 2 also shows that emerging market returns are only weakly correlated with each other. The average correlation between the emerging market returns is only $11 \%$, compared with a correlation of $46 \%$ between the developed market returns.

\footnotetext{
${ }^{13}$ A Wilcoxon rank sum test was used to test the proposition that returns from emerging markets were identical to returns from developed markets. This yielded a test statistic of 0.23 , indicating that the null hypothesis of identical returns could not be rejected.
} 
Table 2 - about here

$* * * * * * * * * * * * * * * * * * * * * * * * * * * * * * * * * * * * * * * *$

\subsection{Political risk measures}

Early political risk analysis revolved around a case study methodology (Ingram 1974; Moran 1974). The advantage of a case study approach is the depth of inquiry. However, it is difficult to make cross-country comparisons based upon case studies. Advances in political risk analysis have since included its quantification as an index (Coplin and O'Leary 1985). Subsequent developments have involved the establishment of quantitative measures and benchmarks of political risk with improvements in reliability and quality.

In this paper, a quantitative measure is required. The proxy used for the political risk variable is the set of risk indices supplied by the Political Risk Services' International Country Risk Guide (ICRG). ${ }^{14}$ The ICRG produces four risk indices including political risk (PR), economic risk (ER), financial risk (FR) indices and an overall composite risk index (CR). Within each of the indices, there are various components. The political risk index consists of thirteen components, the economic risk index consists of six components, and the financial risk index consists of five components. The composite risk index represents an overall risk rating. The composite risk index for each country is determined by combining the political, economic and financial risk indices according to the following:

$$
\mathrm{CR}=0.5 \mathrm{PR}+0.25 \mathrm{ER}+0.25 \mathrm{FR}
$$

For each index, the highest rating of 100 reflects lowest risk, whereas a score of zero reflects the highest risk rating. Political Risk Services Inc. classifies countries into the following broad categories: very high risk is 0 to 49.5 ; high risk is 50.0 to 59.5 ; moderate risk 60.0 to 69.5 ; low risk is 70.0 to 84.5 ; very low risk is 85.0 to 100.0 . Hence, a higher index value implies lower political risk and therefore a negative sign on the ${ }_{{ }_{i}}$ coefficient in (4) is expected.

Details of the risk indices and their components are described in Table 3. Using the definition of political risk of Jodice (1985) all four ICRG indices can be interpreted as being measures, to varying degrees, of 'political risk'. The indices are prepared by market analysts in each country and incorporate the analyst's subjective opinions of potential changes in the constituent elements of each index (see Table 3 for details). Therefore, the indices (potentially) incorporate both the current political climate and expectations of the future political climate in each country. As stock returns are likely to be influenced by both of these types of information

\footnotetext{
${ }^{14}$ Howell and Chaddick (1994) find that Political Risk Services indices are more reliable and are able to predict risk better than those produced by other major political risk information providers.
} 
(ie. current and expected), the political risk variable is measured contemporaneously with returns in the model.

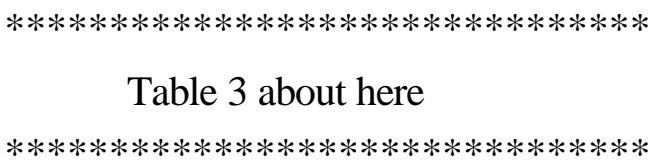

Table 3 about here

$* * * * * * * * * * * * * * * * * * * * * * * * * * * * * * *$

Table 4 - Panel A shows the correlation between the four ICRG indices - political, economic, financial and composite. The correlations vary but are all positive and relatively high. The composite risk index exhibits the highest correlations, as expected, as it is constructed as a function of the other indices. Both developed and emerging market countries exhibit similar relations between the four indices.

$* * * * * * * * * * * * * * * * * * * * * * * * * * * * * * *$

Table 4 - Panel A about here

$* * * * * * * * * * * * * * * * * * * * * * * * * * * * * * *$

Table 4 - Panel B contains descriptive statistics for the political risk index (PR). ${ }^{15}$ Summary figures computed for the two groups of markets (emerging and developed) show that, on average, emerging markets are more politically risky than developed markets (60 vs 82). ${ }^{16}$ Among the emerging markets, Pakistan has the highest average political risk (43), compared to Hong Kong which has the highest average political risk of the developed markets (69). To further illustrate, only one emerging market, Taiwan (77), has a lower average political risk than Hong Kong. ${ }^{17}$ The table also shows that the political risk measure has more variability in emerging markets than in developed markets. Only two developed markets have a standard deviation of political risk over 5.0 (Hong Kong and Italy), compared to eleven of the emerging markets.

$* * * * * * * * * * * * * * * * * * * * * * * * * * * * * * *$

Table 4 - Panel B about here

$* * * * * * * * * * * * * * * * * * * * * * * * * * * * * * *$

\footnotetext{
${ }^{15}$ Descriptive statistics for the other three ICRG indices are quite similar.

${ }^{16}$ Recall that due to the measurement of the ICRG political risk indices, a higher (lower) value of the index represents a lower (higher) measure of risk.

${ }^{17}$ A Wilcoxon Rank Sum Test was employed to determine whether the four ICRG risk indices were identical across emerging and developed markets. The null hypothesis of index equality was rejected, with evidence supporting the alternative hypothesis that developed markets have higher index values (implying lower political risk) than emerging markets ( $\mathrm{p}$-value $=0.00$ ).
} 


\section{Results}

Table 5A contains the results from fitting the International Market Model as in (1) to the emerging market returns. ${ }^{18}$ Results from using the two alternative proxies for the world market portfolio are reported. Emerging markets have little sensitivity to either world index measure and the model explains only a moderate amount of the variation in the returns. The coefficient on the world market is significant in only seven (six) regressions using the MSCI world index (MSCI USA index). This finding indicates that other factors, such as local sources of risk, play a role in explaining return variation in emerging markets.

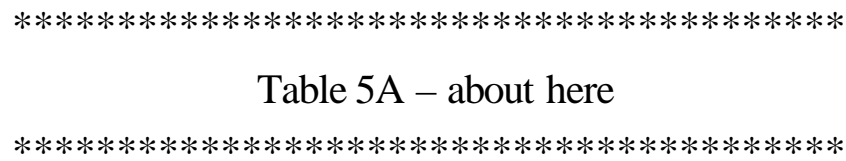

Table 5B contains results from fitting the International Market Model to the returns in developed markets and is presented for comparative purposes. The coefficient on the world market is significant for all of the eighteen markets using the MSCI world index and sixteen markets using the MSCI USA index. The significance of these coefficients is supportive of the world market return capturing the global component of returns. The IMM is able to explain an average of about 40 percent of the variation in the country returns for developed markets, compared with only about 4 percent for the emerging market returns.

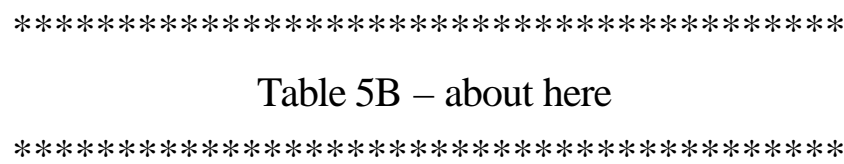

Table 6A contains the results from fitting the primary regression of interest as in (4). ${ }^{19}$ The ICRG political risk variable (PR) is initially employed as the political risk proxy. ${ }^{20}$ Before estimating the regression, stationarity tests are conducted and indicate that for some markets the political risk variable may be non-stationary. While stationarity tests are low in power, as a

\footnotetext{
${ }^{18}$ For the regressions involving the international market model in (1), a least squares procedure was used, with the standard errors adjusted for both serial correlation and heteroskedasticity, as per Newey and West (1987). However, as noted later, for the subsequent regressions that involve the political risk variables the Cochrane-Orcutt two-stage procedure is used. This latter approach is conservative and mitigates non-stationarity concerns regarding the political risk variables.

${ }^{19}$ Given the absence of some data on dividend yield in the early part of the sample, the analysis is conducted on the period December 1985 to December 1997.

${ }^{20}$ For the remaining analysis reported in the paper, the MSCI world index is employed as the proxy for the world market portfolio. The results are very similar if the MSCI USA (country) index is employed as the proxy for the world market portfolio.
} 
precaution against a spurious regression result, the Cochrane-Orcutt method is employed for the regressions reported in Table 6 and all subsequent tables. ${ }^{21}$

In Table 6A, the coefficient estimate on the political risk variable $\left(?_{\mathrm{i}}\right)$ is significant and of the predicted sign in five markets (Chile, Korea, Malaysia, Philippines and Thailand). Further, the sign on the coefficient is generally in the right direction across nearly all markets, suggesting that returns increase as the political risk index decreases (ie. as the country suffers increased political risk).

The control variables appear to be reasonable proxies for the local risk factors, with the average adjusted R-square from the model being 33\% across the emerging markets. The coefficients on the foreign exchange, dividend yield and local volatility variables are significant in nine, eleven and ten markets respectively. The sign of the coefficient on foreign exchange varies, consistent with the argument that the exposure will depend on the industrial structure within a country and the net flow of international funds (Harvey 1995b). The coefficient on the contemporaneous dividend yield variable is consistently negative as expected. The local variance is also significant in several markets indicating that it is a reasonable proxy for omitted local risk sources.

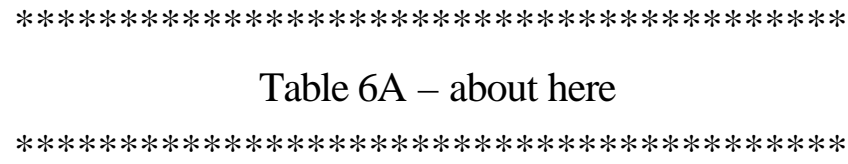

Table 6B contains the results of applying the political risk model to the developed markets. The model performs well, with the average R-square being $38 \%$, driven in part by the dividend yield variable which is significant in every market. Foreign exchange is significant in ten markets, but in contrast to the emerging markets sample, the sign on the coefficient is consistently positive. The local variance is significant in only five markets. The results for the political risk variable are much weaker than in the emerging markets analysis, with only one market experiencing significant exposure (Singapore). These results are consistent with the argument that the influence of political risk is greater in emerging markets than in developed markets.

$$
\begin{aligned}
& \text { ************************************************ } * * * \\
& \text { Table } 6 \mathrm{~B} \text { - about here } \\
& \text { ************************************************* }
\end{aligned}
$$

\footnotetext{
${ }^{21}$ The Cochrane-Orcutt method is asymptotically equivalent to first-differencing both sides of the regression equation (Blough 1986). The regressions were also estimated using the alternative bast squares estimator with the Newey-West correction. The reported results are robust, with increased significance on the political risk coefficient, and the paper's conclusions are unaffected by the alternative procedure.
} 
Of note from both Tables $6 \mathrm{~A}$ and $6 \mathrm{~B}$ is that many of the countries that exhibit a significant exposure to the political risk variable are located in the Pacific-Basin region (ie. Korea, Malaysia, Philippines, Thailand and Singapore). Hence, the PR index may be over-sensitive to regional factors. However, as noted earlier, the PR index supplied by ICRG does not capture all elements of the theoretical concept of political risk. Other elements may be captured in the other ICRG indices. Hence, the analysis now turns to an examination of these alternate indices.

Table 7 contains the results from fitting the political risk model in (4) to the emerging market returns using the four alternative ICRG measures of risk. Recall that in addition to the political risk measure (PR), the other the measures are economic risk (ER), financial risk (FR) and composite risk (CR). The results in Table 7 are generally consistent with the results from using the political risk (PR) measure in Table 6A. This finding is not surprising given the high correlations among the measures of political risk (reported in Table 4 Panel A). Chile, Korea, Mexico, Philippines and Thailand all exhibit significant exposure to at least two of the risk variables. However, there is also evidence that the ICRG indices may capture separate elements of political risk. For example, the return for Malaysia exhibits sensitivity solely to the political risk measure. Of note, all significant coefficients exhibit a negative sign consistent with a positive relation between political risk and ex-post returns.

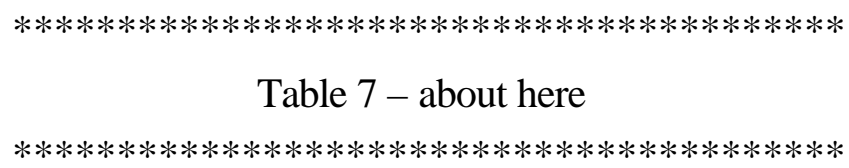

Table 7 - about here

$* * * * * * * * * * * * * * * * * * * * * * * * * * * * * * * * * * * * * * * * *$

The results from Tables $6 \mathrm{~A}, 6 \mathrm{~B}$ and 7 provide some evidence for the proposition that the political risk variable, as a local risk factor, has explanatory power over returns in emerging markets. These results are consistent with those of Erb et al. (1996) who also find a general cross-sectional relation between emerging market returns and political, economic and financial risk measures. ${ }^{22}$ However, the analysis to date has centred on market-specific returns. It is arguable that analysis at this level contains an element of noise induced by idiosyncratic factors. As an analogy, traditional asset pricing tests use portfolios rather than individual stocks to mitigate against noise (eg. Fama and MacBeth 1973). Consequently, the next stage of analysis involves aggregating returns across markets to form three portfolios comprising the sample of emerging markets, developed markets and a combined markets portfolio.

\footnotetext{
${ }^{22}$ As discussed earlier, the method employs contemporaneous observations between the risk and return variables whereas Erb et al. (1996) use a 6-month lag. Further, the method examines the explanatory power of risk variables over the world market returns and local risk proxies, whereas Erb et al. consider only the risk variable in isolation. Hence, the results are not directly comparable.
} 
Table 8 contains pooled regression results from fitting the models in (1) and (4) employing the four alternate measures of political risk. The pooled approach should reveal aggregate relations among the variables whereas the prior analysis (such as Tables 6 and 7) concerned the relations in each market. Thus, in Table 8 , the necessary assumption is made that the cross-sectional units are homogeneous in order to generate a single coefficient for each variable.

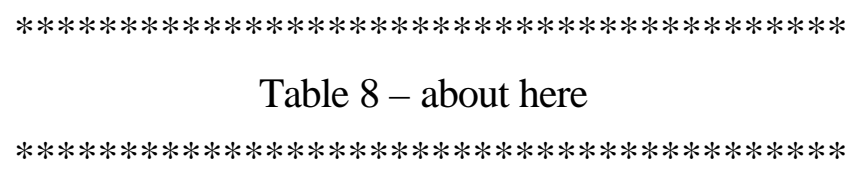

In relation to the IMM (as in (1)), the parameter on the world index is significant for all portfolios. ${ }^{23}$ However, the ability of the IMM to explain return variation in emerging markets is again limited (2\%) compared to the developed markets (36\%). For the political risk model (as in (4)), all measures except the financial risk variable are negative and significant across the emerging markets portfolio, while none of the risk measures are significant in the developed markets portfolio. The last panel in Table 8 presents pooled results across both emerging and developed markets. This combined portfolio exhibits a negative and significant sensitivity to all four of the political risk measures. These results are clearly driven by the emerging markets sample. The findings highlight the dangers of drawing conclusions from aggregated samples.

In summary, there is support for the conjecture that political risk is more important in emerging markets than in developed markets, consistent with the findings of Cosset and Suret (1995) and Diamonte et al. (1996). A final issue that remains is the robustness of the relation between political risk and returns over time.

Table 9 reports on the analysis by sub-sample. The sample is divided into two equal subperiods of six years each. Again a pooled approach is used, and the ICRG political risk index is used in the tests. ${ }^{24}$ The results for the developed markets are consistent with those contained in Tables 6B and 8. That is, the political risk variable is insignificant in both subperiods. In contrast, for the emerging markets the variable is significant and negative in the latter sub-period, again supporting the earlier evidence.

\footnotetext{
${ }^{23}$ These results are not reported to conserve space.

${ }^{24}$ Tests performed using the other political risk measures (not reported here) document similar results. Further, the sample was also segregated into three equal sub-periods of four years each and again the results are consistent with the political risk variable significant in the latter sub-period.
} 
The absence of a significant result in he earlier period for the emerging markets sample suggests that the political risk-return relation is a relatively recent phenomenon. We conjecture at least three explanations for this result. First, it could be that political risk is indeed only relevant as an explanation of returns in the latter period. This may be due to higher variation in political risk in the 1990s, particularly in the last few years of the sample. Second, it is conceivable that the increase in the flow of international funds over time has resulted in an improved price setting process in emerging markets such that specific risks become priced (Bekaert et al. 1999), although the paper does not directly test this issue. In this sense, the political risk variable becomes a proxy measure of integration (as per Perotti and van Oijen 1999). Third, improvements in the collection and reporting of data used in the construction of the risk indices may have occurred over time. As a result, the sensitivity of returns to the risk indices is only apparent in the more recent period.

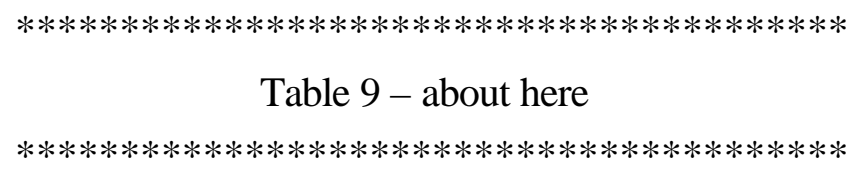

\section{Conclusions}

This paper presents evidence that political risk may be able to explain some of the variation in emerging stock market returns at both the country and aggregate levels. This explanatory power is in addition to that provided by return variation in the world market portfolio and other local factors. At the individual country level, the relation between returns and political risk appears far more prevalent in emerging markets, particularly those in the Pacific-Basin, than in developed markets. Moreover, for developed markets, political risk is insignificant at the aggregate level. The paper shows the aggregate relation between political risk and emerging stock market returns to be most apparent in the most recent sub-period of the 1990s. These results add to the growing literature on the role of political risk and the association with stock market returns, particularly in the context of emerging markets.

The findings raise a number of issues. First, the evidence that there is some political risk exposure in emerging markets that is different to developed markets has implications for asset pricing and portfolio decisions in these markets. Second, a large number of international investors utilise specialist international mutual funds as their investment vehicle to gain access to emerging markets (in contrast to direct foreign share ownership). Hence, these investors are exposed to the 'risk' of the emerging markets portfolio. In this sense, any exposure of emerging markets at the aggregate portfolio level will be borne by such investors. Indeed, the results show that aggregate level exposure to political risk may well exist. Third, there is indirect but suggestive evidence that political risk itself is related to levels of integration which leaves an avenue for future research. 


\section{References}

Adler, M. and B. Dumas, 1983, International portfolio choice and corporation finance: A synthesis, Journal of Finance 38, 925-984.

Aggarwal, R., Inclan, C. and R. Leal, 1999, Volatility in emerging stock markets, Journal of Financial and Quantitative Analysis 34, 33-55.

Aliber, R., 1973, Interest rate parity theorem: A reinterpretation, Journal of Political Economy 81, 1451-59.

Bailey, W. and Y.P. Chung, 1995, Exchange rate fluctuations, political risk and stock returns: Some evidence from an emerging market, Journal of Financial and Quantitative Analysis $30,541-562$.

Bekaert, G., 1995, Market integration and investment barriers in emerging equity markets, World Bank Economic Review 9, 75-107.

Bekaert, G. and C.R. Harvey, 1995, Time-varying world market integration, Journal of Finance 50, 403-44.

Bekaert, G. and C.R. Harvey, 2000, Foreign speculators and emerging equity markets, Journal of Finance 55, 565-613.

Bekaert, G., C.R. Harvey and R.L. Lumsdaine, 1999, The dynamics of emerging market equity flows, Working paper, Stanford University.

Blough, S., 1992, The relationship between power and level for generic unit root tests in finite samples, Journal of Applied Econometrics 7, 295-308.

Bracker, K., D.S. Docking and P.D. Koch, 1999, Economic determinants of evolution in international stock market integration, Journal of Empirical Finance 6, 1-27.

Cherian, J.A. and E.C. Perotti, 1999, Option pricing and foreign investment under political risk, Working paper, University of Amsterdam.

Claessens, S., Dasgupta, S. and J. Glen, 1995, Return behaviour in emerging markets, World Bank Economic Review 9, 131-151.

Coplin, W.D. and M.K. O'Leary, 1985, The world political risk forecasting service, in: T.L. Brewer, ed., Political risks in international business (Praeger, New York).

Cosset, J.C. and J.M. Suret, 1995, Political risk and the benefits of international diversification, Journal of International Business Studies, 301-318.

Demirguc-Kunt, A. and H. Huizinga, 1995, Barriers to portfolio investments in emerging stock markets, Journal of Development Economics 47, 355-74. 
Diamonte, R., Liew, J. and R. Stevens, 1996, Political risk in emerging and developed markets, Financial Analysts Journal, May/June.

Divecha, A., Drach, J. and D. Stefak, 1992, Emerging markets: a quantitative perspective, Journal of Portfolio Management 4, 41-50.

Dumas, B. and B. Solnik, 1995, The world price of foreign exchange risk, Journal of Finance 50, 445-479.

Erb, C., Harvey, C. and T. Viskanta, 1996, Political risk, economic and financial risk, Financial Analysts Journal 52, 29-46.

Errunza, V., 1977, Gains from portfolio diversification in less developed countries' securities, Journal of International Business Studies 8, Fall/Winter, 83-89.

Errunza, V., 1983, Emerging markets: a new opportunity for improving global portfolio performance, Financial Analysts Journal 39, 51-58.

Errunza, V., Losq, E. and P. Padmanabhan, 1992, Tests of integration, mild segmentation and segmentation hypotheses, Journal of Banking and Finance 16, 949-972.

Fama, E.F. and K.R. French, 1988, Dividend yields and expected stock returns, Journal of Financial Economics 22, 3-25.

Fama, E.F. and K.R. French, 1992, The cross-section of expected stock returns, Journal of Finance 47, 427-465.

Fama, E.F. and K.R. French, 1995, Size and book-to-market factors in earnings and returns, Journal of Finance 50, 131-154.

Fama, E.F. and J.D. MacBeth, 1973, Risk, return and equilibrium: empirical tests, Journal of Political Economy 81, 607-36.

Goetzmann, W.N. and Jorion, P., 1999, Re-emerging markets, Journal of Financial and Quantitative Analysis 34, 1-32.

Green, R.T., 1974, Political structures as a predictor of radical political change, Columbia Journal of World Business, Spring, 31-35.

Harvey, C.R., 1995a, The risk exposure of emerging equity markets, World Bank Economic Review 9, 19-50.

Harvey, C.R., 1995b, Predictable risk and return in emerging markets, Review of Financial Studies 8, 773-816.

Henry, P., 2000, Stock market liberalization, economic reform and emerging market equity prices, Journal of Finance 55, 529-564. 
Howell, L.D. and B. Chaddick, 1994, Models of political risk for foreign investment and trade: an assessment of three approaches, Columbia Journal of World Business 29, 7091.

Ingram, G.M., 1974, Expropriation of US property in South America: nationalisation of oil and copper companies in Peru, Bolivia and Chile (Praeger, New York).

Jodice, D.A., 1985, Political risk assessment: an annotated biography (Greenwood Press, Westport).

Jorion, P., 1991, The pricing of exchange rate risk in the stock market, Journal of Financial and Quantitative Analysis 26, 363-376.

Kothari, S.P. and J. Shanken, 1992, Stock return variation and expected dividends, Journal of Financial Economics 31, 177-210.

Moran, T.H., 1974, Multinational corporations and the politics of dependence: copper in Chile (Princeton University Press, Princeton).

Newey, W. and K. West, 1987, A simple, positive semi-definite, heteroskedasticity and autocorrelation consistent covariance matrix, Econometrica 55, 703-708.

Perotti, E.C., 1995, Credible privatization, American Economic Review 85, 847-859.

Perotti, E.C. and P. van Oijen, 1999, Privatization, political risk and stock market development in emerging economies, Working Paper, University of Amsterdam.

Prast, W.G. and H.L. Lax, 1982, Political risk as a variable in the TNC decision-making, Natural Resources Forum 6, 183-191.

Robock, S., 1971, Political risk: identification and assessment, Columbia Journal of World Business, July/August, 6-20.

Schwert, G.W., 1990, Stock Volatility and the Crash, The Review of Financial Studies 3, 77 102.

Solnik, B., 1974, An equilibrium model of the international capital market, Journal of Economic Theory 8, 500-524.

Stulz, R., 1981, A model of international asset pricing, Journal of Financial Economics 9, 383406.

Truit, J., 1974, Expropriation of private foreign investment (University of Indiana Press, Bloomington). 
Table 1

Descriptive Statistics of Monthly Returns for Emerging and Developed Stock

Markets

February 1984 to December 1997

\begin{tabular}{|c|c|c|c|c|c|c|c|c|}
\hline & Mean & $\begin{array}{c}\text { Std } \\
\text { Devn }\end{array}$ & $\begin{array}{c}\text { Skew- } \\
\text { ness }\end{array}$ & $\begin{array}{c}\text { Excess } \\
\text { Kurtosis }\end{array}$ & $\begin{array}{c}\text { Jarque- } \\
\text { Bera }\end{array}$ & $\begin{array}{l}\text { Goodness } \\
\text { of Fit }\end{array}$ & Min & $\operatorname{Max}$ \\
\hline \multicolumn{9}{|c|}{ Emerging stock markets } \\
\hline Argentina & 0.017 & 0.219 & 0.253 & 7.627 & 379.19 & 68.11 & -1.049 & 1.023 \\
\hline Brazil & 0.015 & 0.181 & -0.569 & 2.850 & 60.81 & 22.90 & -0.842 & 0.454 \\
\hline Chile & 0.022 & 0.077 & -0.049 & -0.060 & 0.13 & 10.96 & -0.212 & 0.198 \\
\hline Colombia & 0.024 & 0.079 & 1.126 & 2.838 & 80.05 & 34.79 & -0.192 & 0.317 \\
\hline Greece & 0.014 & 0.104 & 0.830 & 3.864 & 114.78 & 48.03 & -0.368 & 0.461 \\
\hline India & 0.008 & 0.091 & 0.262 & 0.668 & 4.48 & 13.23 & -0.279 & 0.302 \\
\hline Jordan & 0.005 & 0.045 & 0.180 & 1.313 & 11.57 & 29.79 & -0.137 & 0.150 \\
\hline Korea & 0.002 & 0.094 & -0.803 & 3.389 & 91.38 & 37.26 & -0.409 & 0.236 \\
\hline Malaysia & 0.002 & 0.087 & -1.278 & 3.846 & 129.93 & 25.98 & -0.373 & 0.190 \\
\hline Mexico & 0.019 & 0.138 & -2.404 & 13.183 & 1290.18 & 45.85 & -0.899 & 0.333 \\
\hline Nigeria & 0.005 & 0.162 & -3.259 & 26.602 & 4570.45 & 169.40 & -1.211 & 0.691 \\
\hline Pakistan & 0.010 & 0.072 & 0.799 & 3.370 & 83.78 & 46.11 & -0.175 & 0.302 \\
\hline Philippines & 0.019 & 0.102 & -0.057 & 2.170 & 27.75 & 37.38 & -0.347 & 0.354 \\
\hline Taiwan & 0.015 & 0.134 & -0.142 & 1.864 & 20.80 & 39.27 & -0.439 & 0.427 \\
\hline Thailand & 0.004 & 0.100 & -1.218 & 3.919 & 139.28 & 41.40 & -0.413 & 0.279 \\
\hline Venezuela & 0.013 & 0.139 & -1.267 & 6.215 & 273.30 & 32.11 & -0.689 & 0.396 \\
\hline Zimbabwe & 0.015 & 0.101 & -0.862 & 4.697 & 162.56 & 32.53 & -0.488 & 0.378 \\
\hline Average & 0.012 & 0.113 & & & & & -1.211 & 1.023 \\
\hline \multicolumn{9}{|c|}{ Developed stock markets } \\
\hline Australia & 0.009 & 0.076 & -2.994 & 21.967 & 3395.78 & 24.41 & -0.589 & 0.165 \\
\hline Austria & 0.013 & 0.073 & 0.170 & 2.116 & 29.11 & 31.11 & -0.365 & 0.248 \\
\hline Belgium & 0.017 & 0.053 & 0.374 & 4.213 & 118.06 & 25.25 & -0.209 & 0.237 \\
\hline Canada & 0.008 & 0.045 & -0.848 & 5.440 & 210.91 & 10.00 & -0.249 & 0.137 \\
\hline Denmark & 0.011 & 0.056 & -0.005 & 0.400 & 0.86 & 12.82 & -0.133 & 0.193 \\
\hline France & 0.014 & 0.062 & -0.256 & 0.942 & 7.15 & 16.05 & -0.203 & 0.191 \\
\hline Germany & 0.013 & 0.063 & -0.507 & 1.512 & 21.29 & 30.90 & -0.194 & 0.184 \\
\hline Hong Kong & 0.016 & 0.087 & -2.193 & 12.789 & 1196.89 & 36.88 & -0.570 & 0.243 \\
\hline Italy & 0.012 & 0.074 & 0.213 & 0.455 & 2.39 & 6.94 & -0.206 & 0.270 \\
\hline Japan & 0.007 & 0.074 & 0.033 & 0.376 & 0.79 & 13.38 & -0.215 & 0.217 \\
\hline Netherlands & 0.016 & 0.046 & -0.690 & 2.245 & 44.94 & 7.92 & -0.191 & 0.143 \\
\hline Norway & 0.011 & 0.072 & -0.803 & 2.161 & 47.19 & 8.46 & -0.326 & 0.148 \\
\hline Singapore & 0.005 & 0.074 & -2.280 & 16.353 & 1886.29 & 33.39 & -0.533 & 0.201 \\
\hline Spain & 0.018 & 0.068 & -0.077 & 1.375 & 11.90 & 13.64 & -0.230 & 0.237 \\
\hline Sweden & 0.014 & 0.067 & -0.484 & 0.845 & 10.67 & 7.26 & -0.241 & 0.159 \\
\hline Switzerland & 0.016 & 0.052 & -0.311 & 1.290 & 12.93 & 9.76 & -0.194 & 0.154 \\
\hline UK & 0.014 & 0.056 & -0.454 & 1.879 & 27.85 & 8.34 & -0.243 & 0.148 \\
\hline USA & 0.013 & 0.042 & -1.327 & 7.010 & 366.70 & 15.24 & -0.239 & 0.125 \\
\hline Average & 0.013 & 0.063 & & & & & -0.589 & 0.270 \\
\hline World Index & 0.012 & 0.041 & -0.738 & 2.876 & 67.67 & 18.78 & -0.185 & 0.111 \\
\hline
\end{tabular}

Notes:

(a) All statistics are based on the monthly US dollar return for each country index.

(b) Return data for the emerging markets are obtained from the International Finance Corporation (IFC)

Global Indices. The developed market returns are from Morgan Stanley Capital International (MSCI).

(c) The world index return is the US dollar return on the MSCI value-weighted world market portfolio.

(d) The sample period spans February 1984 to December 1997 except in the following cases where data are unavailable in the early months: Colombia, Malaysia, Nigeria, Pakistan, Philippines, Taiwan, Venezuela (all from February 1985) and Korea (from April 1985). 
Table 2

\section{Correlation Matrix of Developed and Emerging Stock Market Monthly Returns}

\section{January 1985 to December 1997}

\begin{tabular}{|c|c|c|c|c|c|c|c|c|c|c|c|c|c|c|c|c|c|c|c|c|c|c|c|c|c|c|c|c|c|c|c|c|c|c|c|}
\hline & $A G$ & BR & $C L$ & CB & GR & IN & JO & MY & MX & $N G$ & PK & $\mathrm{PH}$ & TA & TH & VE & $\mathrm{RH}$ & $\mathrm{OZ}$ & $\mathrm{AU}$ & BE & $\mathrm{CA}$ & $\mathrm{DE}$ & FR & GE & HK & IT & JA & NE & NO & SI & SP & SE & SW & UK & US & WI \\
\hline$\overline{A G}$ & 1.00 & & & & & & & & & & & & & & & & & & & & & & & & & & & & & & & & & & \\
\hline BR & 0.01 & 1.00 & & & & & & & & & & & & & & & & & & & & & & & & & & & & & & & & & \\
\hline$\overline{C L}$ & 0.08 & 0.16 & 1.00 & & & & & & & & & & & & & & & & & & & & & & & & & & & & & & & & \\
\hline $\mathrm{CB}$ & -0.04 & 0.05 & 0.10 & 1.00 & & & & & & & & & & & & & & & & & & & & & & & & & & & & & & & \\
\hline GR & 0.05 & 0.03 & 0.19 & 0.23 & 1.00 & & & & & & & & & & & & & & & & & & & & & & & & & & & & & & \\
\hline $\mathbb{I N}$ & 0.17 & 0.08 & 0.18 & 0.05 & 0.10 & 1.00 & & & & & & & & & & & & & & & & & & & & & & & & & & & & & \\
\hline $\mathrm{JO}$ & -0.08 & 0.03 & 0.03 & 0.04 & 0.05 & 0.11 & 1.00 & & & & & & & & & & & & & & & & & & & & & & & & & & & & \\
\hline$\overline{M Y}$ & 0.01 & 0.11 & 0.26 & 0.03 & 0.11 & 0.09 & 0.07 & 1.00 & & & & & & & & & & & & & & & & & & & & & & & & & & & \\
\hline$\overline{M X}$ & 0.20 & 0.08 & 0.35 & 0.02 & 0.15 & 0.07 & 0.01 & 0.34 & 1.00 & & & & & & & & & & & & & & & & & & & & & & & & & & \\
\hline $\mathrm{NG}$ & 0.00 & 0.05 & 0.04 & 0.17 & 0.05 & 0.01 & 0.03 & -0.11 & -0.04 & 1.00 & & & & & & & & & & & & & & & & & & & & & & & & & \\
\hline PK & 0.04 & 0.04 & 0.13 & 0.33 & 0.03 & 0.15 & 0.17 & 0.16 & 0.13 & 0.09 & 1.00 & & & & & & & & & & & & & & & & & & & & & & & & \\
\hline $\mathrm{PH}$ & -0.01 & 0.12 & 0.27 & 0.13 & 0.16 & 0.00 & 0.06 & 0.50 & 0.16 & 0.01 & 0.17 & 1.00 & & & & & & & & & & & & & & & & & & & & & & & \\
\hline TA & 0.03 & 0.10 & 0.30 & 0.12 & 0.09 & -0.02 & 0.07 & 0.30 & 0.30 & -0.10 & 0.08 & 0.21 & 1.00 & & & & & & & & & & & & & & & & & & & & & & \\
\hline $\mathrm{TH}$ & 0.10 & 0.07 & 0.34 & 0.08 & 0.24 & 0.13 & 0.17 & 0.63 & 0.33 & -0.05 & 0.27 & 0.45 & 0.37 & 1.00 & & & & & & & & & & & & & & & & & & & & & \\
\hline VE & 0.08 & -0.07 & -0.06 & 0.15 & 0.01 & 0.11 & 0.11 & 0.05 & -0.02 & \begin{tabular}{|c|}
0.08 \\
\end{tabular} & 0.11 & \begin{tabular}{|c|}
-0.03 \\
\end{tabular} & -0.09 & 0.00 & 1.00 & & & & & & & & & & & & & & & & & & & & \\
\hline $\mathrm{ZI}$ & -0.11 & 0.01 & 0.11 & 0.04 & 0.05 & 0.08 & 0.04 & 0.20 & 0.00 & 0.08 & 0.12 & 0.18 & 0.00 & 0.17 & 0.19 & 1.00 & & & & & & & & & & & & & & & & & & & \\
\hline$\overline{\mathrm{AA}}$ & 0.15 & 0.15 & 0.20 & 0.01 & 0.17 & 0.10 & 0.16 & 0.42 & 0.28 & \begin{tabular}{|c|}
-0.04 \\
\end{tabular} & 0.08 & 0.21 & 0.30 & 0.41 & 0.05 & -0.02 & 1.00 & & & & & & & & & & & & & & & & & & \\
\hline$\overline{\mathrm{Al}}$ & -0.04 & 0.11 & 0.19 & 0.08 & 0.30 & 0.17 & 0.15 & 0.25 & 0.06 & 0.04 & 0.19 & 0.23 & 0.24 & 0.28 & -0.09 & 0.10 & 0.18 & 1.00 & & & & & & & & & & & & & & & & & \\
\hline $\mathrm{BE}$ & 0.00 & 0.09 & 0.22 & 0.05 & 0.16 & 0.03 & 0.17 & 0.27 & 0.25 & \begin{tabular}{l|l|}
-0.01 \\
\end{tabular} & 0.14 & 0.34 & 0.23 & 0.35 & -0.02 & -0.05 & 0.33 & 0.37 & 1.00 & & & & & & & & & & & & & & & & \\
\hline$\overline{C A}$ & 0.08 & 0.10 & 0.26 & 0.07 & 0.19 & -0.03 & 0.08 & 0.45 & 0.32 & 0.02 & 0.09 & 0.32 & 0.20 & 0.37 & 0.13 & 0.05 & 0.60 & 0.20 & 0.42 & 1.00 & & & & & & & & & & & & & & & \\
\hline $\mathrm{DE}$ & 0.01 & 0.03 & 0.05 & 0.07 & 0.15 & 0.08 & 0.27 & 0.18 & 0.00 & 0.17 & 0.17 & 0.17 & 0.03 & 0.12 & -0.06 & 0.05 & 0.26 & 0.30 & 0.52 & 0.34 & 1.00 & & & & & & & & & & & & & & \\
\hline $\begin{array}{l}\mathrm{FR} \\
\end{array}$ & 0.07 & 0.06 & 0.16 & 0.00 & 0.26 & 0.13 & 0.06 & 0.23 & 0.21 & \begin{tabular}{|c|}
-0.08 \\
\end{tabular} & 0.08 & 0.26 & 0.21 & 0.25 & -0.05 & -0.03 & 0.33 & 0.47 & $\begin{array}{ll}0.72 \\
\end{array}$ & 0.42 & 0.49 & 1.00 & & & & & & & & & & & & & \\
\hline$\overline{\mathrm{GE}}$ & -0.01 & 0.10 & 0.14 & 0.01 & 0.20 & 0.02 & 0.12 & 0.27 & 0.19 & 0.06 & 0.14 & 0.28 & 0.20 & 0.29 & -0.17 & 0.01 & 0.33 & 0.62 & 0.66 & 0.33 & 0.55 & 0.71 & 1.00 & & & & & & & & & & & & \\
\hline $\mathrm{HK}$ & -0.01 & 0.16 & 0.37 & 0.08 & 0.18 & 0.02 & 0.17 & 0.61 & 0.37 & -0.07 & 0.23 & 0.43 & 0.32 & 0.59 & 0.07 & 0.05 & 0.58 & 0.33 & 0.39 & \begin{tabular}{|l|}
0.63 \\
\end{tabular} & 0.26 & 0.39 & \begin{tabular}{l|l}
0.38 \\
\end{tabular} & 1.00 & & & & & & & & & & & \\
\hline IT & 0.03 & 0.13 & 0.10 & 0.13 & 0.19 & 0.01 & 0.12 & 0.10 & 0.05 & 0.15 & 0.12 & 0.24 & 0.15 & 0.20 & -0.02 & 0.03 & 0.20 & 0.35 & 0.44 & 0.33 & 0.40 & 0.50 & 0.49 & 0.24 & 1.00 & & & & & & & & & & \\
\hline $\mathrm{JA}$ & -0.05 & 0.14 & 0.06 & \begin{tabular}{|l|l|}
0.03 \\
\end{tabular} & 0.07 & -0.11 & 0.10 & $\begin{array}{l}0.22 \\
\end{array}$ & 0.12 & 0.09 & $\begin{array}{l}0.03 \\
\end{array}$ & 0.23 & 0.20 & 0.20 & \begin{tabular}{|c|}
-0.03 \\
\end{tabular} & 0.13 & 0.22 & 0.17 & 0.43 & 0.26 & 0.34 & 0.43 & 0.30 & 0.20 & 0.39 & 1.00 & & & & & & & & & \\
\hline $\mathrm{NE}$ & 0.02 & 0.11 & 0.15 & 0.06 & 0.23 & 0.07 & 0.14 & 0.39 & 0.23 & 0.05 & 0.16 & 0.32 & 0.13 & 0.34 & 0.00 & 0.01 & 0.48 & 0.45 & 0.67 & 0.61 & 0.54 & 0.68 & \begin{tabular}{l|l}
0.73 \\
\end{tabular} & 0.52 & 0.40 & 0.43 & 1.00 & & & & & & & & \\
\hline NO & 0.01 & 0.17 & 0.23 & 0.02 & 0.21 & 0.07 & 0.08 & 0.41 & 0.35 & 0.03 & 0.06 & 0.17 & 0.22 & 0.27 & 0.00 & 0.13 & 0.50 & 0.34 & 0.51 & 0.51 & 0.47 & 0.45 & 0.49 & 0.44 & 0.32 & 0.25 & 0.64 & 1.00 & & & & & & & \\
\hline $\mathrm{SI}$ & 0.05 & 0.10 & 0.31 & 0.07 & 0.17 & 0.00 & 0.11 & 0.79 & 0.40 & -0.11 & 0.11 & 0.44 & 0.38 & 0.61 & 0.05 & 0.05 & 0.57 & 0.23 & 0.39 & 0.52 & 0.29 & 0.31 & 0.31 & 0.69 & 0.22 & \begin{tabular}{l|l}
0.28 \\
\end{tabular} & 0.45 & 0.49 & 1.00 & & & & & & \\
\hline $\mathrm{SP}$ & 0.09 & 0.19 & 0.30 & 0.11 & 0.24 & 0.03 & 0.07 & 0.20 & 0.20 & 0.20 & 0.00 & 0.32 & 0.19 & 0.23 & -0.05 & 0.02 & 0.46 & 0.34 & 0.55 & 0.44 & 0.51 & 0.59 & \begin{tabular}{l|l}
0.48 \\
\end{tabular} & 0.46 & 0.52 & 0.50 & 0.58 & \begin{tabular}{l|l}
0.48 \\
\end{tabular} & 0.38 & 1.00 & & & & & \\
\hline $\mathrm{SE}$ & -0.01 & 0.26 & 0.21 & 0.06 & 0.21 & 0.02 & 0.10 & 0.34 & 0.30 & 0.02 & 0.05 & 0.28 & 0.20 & 0.31 & -0.06 & 0.03 & 0.45 & 0.32 & \begin{tabular}{l|l}
0.48 \\
\end{tabular} & 0.43 & 0.41 & 0.48 & 0.50 & 0.45 & 0.46 & \begin{tabular}{|c|}
0.43 \\
\end{tabular} & 0.60 & 0.59 & 0.45 & \begin{tabular}{l|l}
0.62 \\
\end{tabular} & 1.00 & & & & \\
\hline SW & 0.01 & 0.14 & 0.12 & 0.07 & 0.21 & 0.10 & 0.24 & 0.26 & 0.19 & 0.05 & 0.08 & 0.19 & 0.09 & 0.27 & -0.10 & -0.08 & 0.36 & 0.46 & 0.59 & \begin{tabular}{l|}
0.46 \\
\end{tabular} & 0.52 & 0.61 & \begin{tabular}{l|l}
0.68 \\
\end{tabular} & \begin{tabular}{l|l|}
0.39 \\
\end{tabular} & 0.38 & \begin{tabular}{l|}
0.38 \\
\end{tabular} & \begin{tabular}{|l|}
0.73 \\
\end{tabular} & \begin{tabular}{l|}
0.49 \\
\end{tabular} & 0.34 & \begin{tabular}{l|}
0.51 \\
\end{tabular} & 0.56 & 1.00 & & & \\
\hline UK & -0.04 & 0.11 & 0.15 & 0.05 & 0.16 & 0.02 & 0.21 & 0.38 & 0.23 & 0.00 & 0.12 & 0.18 & 0.15 & 0.25 & 0.10 & 0.03 & 0.53 & 0.38 & 0.59 & \begin{tabular}{l|}
0.57 \\
\end{tabular} & 0.49 & 0.60 & \begin{tabular}{l|l}
0.53 \\
\end{tabular} & \begin{tabular}{l|l}
0.50 \\
\end{tabular} & 0.33 & \begin{tabular}{|l|l|}
0.40 \\
\end{tabular} & \begin{tabular}{l|l|}
0.74 \\
\end{tabular} & \begin{tabular}{l|l}
0.63 \\
\end{tabular} & 0.50 & \begin{tabular}{l|l}
0.58 \\
\end{tabular} & 0.57 & 0.63 & 1.00 & & \\
\hline US & 0.09 & 0.14 & 0.29 & 0.06 & 0.16 & -0.03 & 0.07 & 0.41 & 0.41 & 0.01 & 0.08 & 0.24 & 0.19 & 0.32 & -0.03 & -0.01 & 0.46 & 0.15 & 0.48 & \begin{tabular}{|l|}
0.75 \\
\end{tabular} & 0.32 & 0.50 & 0.40 & \begin{tabular}{l|l}
0.54 \\
\end{tabular} & 0.28 & \begin{tabular}{|l|}
0.22 \\
\end{tabular} & \begin{tabular}{l|}
0.62 \\
\end{tabular} & \begin{tabular}{l|}
0.52 \\
\end{tabular} & 0.55 & \begin{tabular}{l|l}
0.47 \\
\end{tabular} & 0.47 & 0.51 & 0.60 & 1.00 & \\
\hline WI & 0.00 & 0.19 & 0.20 & 0.06 & 0.19 & -0.06 & 0.15 & 0.43 & 0.32 & 0.05 & 0.09 & 0.33 & 0.27 & 0.36 & \begin{tabular}{l|l|} 
\\
\end{tabular} & 0.06 & 0.50 & 0.32 & 0.67 & \begin{tabular}{l|l|}
0.66 \\
\end{tabular} & 0.52 & 0.69 & \begin{tabular}{ll|}
0.58 \\
\end{tabular} & \begin{tabular}{l|l|}
0.54 \\
\end{tabular} & 0.51 & \begin{tabular}{|l|}
0.76 \\
\end{tabular} & \begin{tabular}{l|l}
0.77 \\
\end{tabular} & \begin{tabular}{l|l|}
0.58 \\
\end{tabular} & 0.56 & \begin{tabular}{l|l|}
0.70 \\
\end{tabular} & \begin{tabular}{l|l|}
0.66 \\
\end{tabular} & 0.67 & 0.75 & \begin{tabular}{l|l|}
0.74 \\
\end{tabular} & 1.00 \\
\hline & $\overline{A G}$ & $\mathrm{BR}$ & $\mathrm{CL}$ & CB & GR & IN & $\mathrm{JO}$ & MY & $\mathrm{MX}$ & NG & PK & $\mathrm{PH}$ & TA & $\mathrm{TH}$ & VE & $\mathrm{RH}$ & $\mathrm{OZ}$ & $\mathrm{AU}$ & $\mathrm{BE}$ & $\mathrm{CA}$ & $\mathrm{DE}$ & FR & GE & $\mathrm{HK}$ & IT & JA & $\mathrm{NE}$ & NO & $\mathrm{SI}$ & SP & SE & SW & UK & US & $\mathrm{WI}$ \\
\hline
\end{tabular}

Notes: AG=Argentina, BR=Brazil, $\mathrm{CL}=$ Chile, $\mathrm{CB}=$ Colombia, $\mathrm{GR}=$ Greece, IN=India, JO=Jordan, MY=Malaysia, MX=Mexico, NG=Nigeria, $\mathrm{PK}=\mathrm{Pakistan}, \mathrm{PH}=\mathrm{Philippines,} \mathrm{TA=Taiwan,}$

$\mathrm{TH}=$ Thailand, VE=Venezuela, ZI=Zimbabwe, AA=Australia, AI=Austria, BE=Belgium, CA=Canada, DE=Denmark, FR=France, GE=Germany, HK=Hong Kong, IT=Italy, JA=Japan,

NE=Netherlands, NO=Norway, SI=Singapore, SP=Spain, SE=Sweden, SW=Switzerland, UK=United Kingdom, US=United States of America and WI=MSCI World Index 
Table 3

Details of the ICRG Risk Indices and their Components

\begin{tabular}{|c|c|c|c|}
\hline Factor & Points & $\%$ of Index & $\begin{array}{l}\% \text { of } \\
\text { Composite } \\
\text { Index }\end{array}$ \\
\hline \multicolumn{4}{|l|}{ Political Risk } \\
\hline Economic expectations versus reality & 12 & 12 & 6 \\
\hline Economic planning failures & 12 & 12 & 6 \\
\hline Political leadership & 12 & 12 & 6 \\
\hline External conflict & 10 & 10 & 5 \\
\hline Corruption in government & 6 & 6 & 3 \\
\hline Military in politics & 6 & 6 & 3 \\
\hline Organised religion in politics & 6 & 6 & 3 \\
\hline Law and order tradition & 6 & 6 & 3 \\
\hline Racial and national tensions & 6 & 6 & 3 \\
\hline Political terrorism & 6 & 6 & 3 \\
\hline Civil war & 6 & 6 & 3 \\
\hline Political party development & 6 & 6 & 3 \\
\hline Quality of bureaucracy & 6 & 6 & 3 \\
\hline Total Political Points & 100 & 100 & $\mathbf{5 0}$ \\
\hline \multicolumn{4}{|l|}{ Economic Risk } \\
\hline Inflation & 10 & 20 & 5 \\
\hline $\begin{array}{l}\text { Debt service as a percentage of exports of goods } \\
\text { and services }\end{array}$ & 10 & 20 & 5 \\
\hline International liquidity ratios & 5 & 10 & 3 \\
\hline Foreign trade collection experience & 5 & 10 & 3 \\
\hline $\begin{array}{l}\text { Current account bala nce as a percentage of goods } \\
\text { and services }\end{array}$ & 15 & 30 & 8 \\
\hline Parallel foreign exchange market indicators & 5 & 10 & 3 \\
\hline Total Economic Points & 50 & 100 & 25 \\
\hline \multicolumn{4}{|l|}{ Financial } \\
\hline Loan default or unfavourable loan restructuring & 10 & 20 & 5 \\
\hline Delayed payments of suppliers; credits & 10 & 20 & 5 \\
\hline Repudiation of contracts by governments & 10 & 20 & 5 \\
\hline Losses from exchange controls & 10 & 20 & 5 \\
\hline Expropriation of private investments & 10 & 20 & 5 \\
\hline Total Financial Points & 50 & 100 & 25 \\
\hline
\end{tabular}

Note: Rounding errors lead to some minor variation between individual percentage entries and the total percentages. 
Table 4 - Panel A

\section{Correlation between ICRG Risk Indices}

February 1984 to December 1997

\begin{tabular}{|c|c|c|c|c|c|}
\hline & & & & & \\
\hline & & PR & ER & FR & CR \\
\hline Emerging Stock & PR & 1.00 & & & \\
\hline Markets & ER & 0.47 & 1.00 & & \\
\hline & FR & 0.60 & 0.35 & 1.00 & \\
\hline & CR & 0.92 & 0.65 & 0.81 & 1.00 \\
\hline & & & & & \\
\hline & & PR & ER & FR & CR \\
\hline Developed Stock & PR & 1.00 & & & \\
\hline Markets & ER & 0.36 & 1.00 & & \\
\hline & FR & 0.69 & 0.68 & 1.00 & \\
\hline & CR & 0.88 & 0.71 & 0.92 & 1.00 \\
\hline & & & & & \\
\hline
\end{tabular}

The following abbreviations are used for the ICRG risk indices: PR - Political Risk, ER - Economic Risk, FR - Financial Risk, and CR - Composite Risk. 
Table 4 - Panel B

\section{Descriptive Statistics for the ICRG Political Risk Index February 1984 to December 1997}

\begin{tabular}{|c|c|c|c|c|c|c|c|}
\hline & Mean & $\begin{array}{c}\text { Std } \\
\text { Devn }\end{array}$ & $\begin{array}{c}\text { Skew- } \\
\text { ness }\end{array}$ & $\begin{array}{c}\text { Excess } \\
\text { Kurtosis } \\
\end{array}$ & $\begin{array}{c}\text { Jarque- } \\
\text { Bera } \\
\end{array}$ & Min & $\operatorname{Max}$ \\
\hline \multicolumn{8}{|c|}{ Emerging stock markets } \\
\hline Argentina & 64.33 & 8.27 & 0.13 & -1.51 & 0.39 & 50 & 77 \\
\hline Brazil & 65.02 & 2.83 & -0.97 & 2.61 & 1.60 & 55 & 71 \\
\hline Chile & 61.98 & 12.21 & -0.19 & -1.23 & 0.27 & 43 & 82 \\
\hline Colombia & 57.57 & 4.60 & -0.86 & 0.79 & 0.47 & 43 & 68 \\
\hline Greece & 66.14 & 7.01 & 0.96 & -0.15 & 0.47 & 58 & 84 \\
\hline India & 51.61 & 9.78 & 0.00 & -0.96 & 0.15 & 30 & 69 \\
\hline Jordan & 55.13 & 13.22 & 0.22 & -1.60 & 0.45 & 34 & 76 \\
\hline Korea & 69.43 & 7.51 & 0.16 & -1.57 & 0.42 & 59 & 83 \\
\hline Malaysia & 69.46 & 6.34 & -0.24 & -0.88 & 0.16 & 57 & 82 \\
\hline Mexico & 67.48 & 3.60 & -0.13 & -0.64 & 0.08 & 60 & 78 \\
\hline Nigeria & 47.74 & 4.90 & -0.19 & -1.20 & 0.26 & 37 & 56 \\
\hline Pakistan & 43.32 & 9.75 & 0.60 & -0.67 & 0.26 & 27 & 65 \\
\hline Philippines & 49.39 & 11.58 & 0.60 & -1.01 & 0.35 & 33 & 76 \\
\hline Taiwan & 76.97 & 2.80 & -0.33 & 0.18 & 0.06 & 71 & 83 \\
\hline Thailand & 61.95 & 6.25 & 0.79 & -0.24 & 0.32 & 53 & 79 \\
\hline Venezuela & 65.63 & 3.75 & 0.67 & 1.48 & 0.59 & 55 & 75 \\
\hline Zimbabwe & 54.79 & 9.28 & -0.06 & -1.35 & 0.31 & 37 & 68 \\
\hline Average & 60.18 & 7.26 & & & & & \\
\hline \multicolumn{8}{|c|}{ Developed stock markets } \\
\hline Australia & 81.85 & 3.91 & 0.38 & -0.84 & 0.18 & 74 & 90 \\
\hline Austria & 86.19 & 3.02 & -0.58 & 0.60 & 0.23 & 78 & 93 \\
\hline Belgium & 80.38 & 2.76 & 0.39 & 0.74 & 0.17 & 74 & 91 \\
\hline Canada & 82.75 & 2.56 & 0.75 & -0.25 & 0.29 & 78 & 88 \\
\hline Denmark & 86.01 & 2.94 & 0.50 & -0.36 & 0.15 & 81 & 93 \\
\hline France & 79.62 & 2.09 & -0.06 & 0.59 & 0.06 & 74 & 85 \\
\hline Germany & 83.23 & 3.99 & -0.76 & 0.24 & 0.30 & 73 & 89 \\
\hline Hong Kong & 69.06 & 7.26 & -0.66 & 0.31 & 0.24 & 52 & 83 \\
\hline Italy & 75.30 & 5.03 & 0.21 & -0.81 & 0.13 & 66 & 86 \\
\hline Japan & 84.83 & 4.70 & -0.10 & -1.01 & 0.17 & 75 & 94 \\
\hline Netherlands & 86.90 & 3.33 & 0.16 & -1.11 & 0.22 & 82 & 93 \\
\hline Norway & 85.71 & 4.12 & 0.11 & -0.71 & 0.09 & 79 & 94 \\
\hline Singapore & 80.51 & 4.16 & 1.01 & -0.19 & 0.51 & 75 & 90 \\
\hline Spain & 72.08 & 3.79 & 0.42 & 0.03 & 0.09 & 64 & 82 \\
\hline Sweden & 84.98 & 3.99 & -0.19 & -1.57 & 0.43 & 78 & 90 \\
\hline Switzerland & 90.76 & 4.11 & -0.36 & -1.30 & 0.35 & 84 & 97 \\
\hline UK & 81.24 & 4.22 & 0.71 & -0.50 & 0.30 & 74 & 91 \\
\hline USA & 82.81 & 4.41 & 0.56 & 0.39 & 0.18 & 74 & 95 \\
\hline Average & 81.90 & 3.91 & & & & & \\
\hline
\end{tabular}

Notes:

(a) The data concern the ICRG political risk index (PR).

(b) The sample period spans February 1984 to December 1997 except in the following cases where data are unavailable in the early months: Colombia, Malaysia, Nigeria, Pakistan, Philippines, Taiwan, Venezuela (all from February 1985) and Korea (from April 1985). 
Table 5A

\section{Emerging Stock Markets - International Market Model February 1984 to December 1997}

$$
\mathrm{R}_{\mathrm{it}}=?{ }_{\mathrm{i}}+?{ }_{\mathrm{i}} \mathrm{R}_{\mathrm{wt}}+\mathrm{r}_{\mathrm{it}} \quad \ldots(1)
$$

\begin{tabular}{|c|c|c|c|c|c|c|}
\hline & \multicolumn{3}{|c|}{ MSCI World Index } & \multicolumn{3}{|c|}{ MSCI USA Index } \\
\hline Country & $?_{\mathrm{i}}$ & $?_{\mathrm{i}}$ & Adjusted $\mathrm{R}^{2}$ & $?_{\mathrm{i}}$ & $?_{\mathrm{i}}$ & Adjusted $\mathrm{R}^{2}$ \\
\hline \multirow{2}{*}{ Argentina } & 0.019 & 0.089 & -0.006 & 0.011 & 0.444 & 0.001 \\
\hline & $(0.87)$ & $(0.16)$ & & $(0.60)$ & $(1.03)$ & \\
\hline \multirow[t]{2}{*}{ Brazil } & 0.011 & $0.775^{*}$ & 0.026 & 0.007 & 0.580 & 0.013 \\
\hline & $(0.43)$ & $(2.06)$ & & $(0.53)$ & $(1.83)$ & \\
\hline \multirow[t]{2}{*}{ Chile } & $0.022 *$ & 0.335 & 0.027 & $0.016^{*}$ & $0.467 *$ & 0.060 \\
\hline & $(2.59)$ & $(1.86)$ & & $(2.29)$ & $(2.74)$ & \\
\hline \multirow[t]{2}{*}{ Colombia } & $0.020 *$ & 0.109 & -0.003 & $0.022 *$ & 0.108 & -0.003 \\
\hline & $(2.83)$ & $(0.83)$ & & $(2.88)$ & $(0.91)$ & \\
\hline \multirow[t]{2}{*}{ Greece } & 0.010 & $0.477 *$ & 0.031 & 0.009 & $0.381^{*}$ & 0.018 \\
\hline & $(0.99)$ & $(2.54)$ & & $(1.02)$ & $(2.11)$ & \\
\hline \multirow[t]{2}{*}{ India } & 0.010 & -0.122 & -0.003 & 0.009 & -0.073 & -0.005 \\
\hline & (1.18) & $(-0.70)$ & & (1.13) & $(-0.55)$ & \\
\hline \multirow[t]{2}{*}{ Jordan } & 0.004 & 0.161 & 0.016 & 0.004 & 0.067 & -0.002 \\
\hline & $(0.96)$ & $(1.68)$ & & $(1.16)$ & $(0.69)$ & \\
\hline \multirow[t]{2}{*}{ Korea } & -0.006 & 0.627 & 0.076 & -0.004 & $0.340^{*}$ & 0.023 \\
\hline & $(-0.61)$ & $(3.73)$ & & $(-0.36)$ & $(2.16)$ & \\
\hline \multirow[t]{2}{*}{ Malaysia } & -0.010 & $0.895^{*}$ & 0.177 & -0.010 & $0.840^{*}$ & 0.164 \\
\hline & $(-1.14)$ & $(4.21)$ & & $(-1.28)$ & $(4.34)$ & \\
\hline \multirow[t]{2}{*}{ Mexico } & 0.011 & $0.966^{*}$ & 0.079 & 0.003 & $1.236^{*}$ & 0.139 \\
\hline & $(0.56)$ & $(2.55)$ & & $(0.18)$ & $(2.73)$ & \\
\hline \multirow[t]{2}{*}{ Nigeria } & 0.002 & 0.200 & -0.004 & 0.004 & 0.057 & -0.006 \\
\hline & $(0.20)$ & $(0.67)$ & & $(0.34)$ & $(0.29)$ & \\
\hline \multirow[t]{2}{*}{ Pakistan } & 0.010 & 0.154 & 0.001 & 0.008 & 0.139 & 0.000 \\
\hline & $(1.20)$ & $(1.22)$ & & $(1.22)$ & $(0.94)$ & \\
\hline \multirow[t]{2}{*}{ Philippines } & 0.010 & $0.815^{*}$ & 0.103 & 0.011 & $0.586^{*}$ & 0.053 \\
\hline & $(0.92)$ & $(3.62)$ & & $(1.05)$ & $(2.52)$ & \\
\hline \multirow[t]{2}{*}{ Taiwan } & 0.001 & $0.886^{*}$ & 0.069 & 0.006 & 0.610 & 0.031 \\
\hline & $(0.35)$ & $(2.62)$ & & $(0.53)$ & $(1.81)$ & \\
\hline \multirow[t]{2}{*}{ Thailand } & -0.010 & $0.857^{*}$ & 0.120 & -0.006 & $0.767^{*}$ & 0.099 \\
\hline & $(-0.62)$ & $(3.40)$ & & $(-0.65)$ & $(3.23)$ & \\
\hline \multirow[t]{2}{*}{ Venezuela } & 0.020 & -0.128 & -0.005 & 0.015 & -0.114 & -0.005 \\
\hline & $(1.17)$ & $(-0.43)$ & & $(1.23)$ & $(-0.44)$ & \\
\hline \multirow[t]{2}{*}{ Zimbabwe } & 0.013 & 0.104 & -0.005 & $0.016^{*}$ & -0.062 & -0.005 \\
\hline & $(1.51)$ & $(0.58)$ & & $(1.77)$ & $(-0.36)$ & \\
\hline
\end{tabular}

Notes:

(a) Standard errors are corrected using the Newey and West (1987) procedure for both autocorrelation and heteroskedasticity of an unknown form.

(b) T-statistics appear in parentheses and are a test of the null hypothesis that the coefficient is equal to zero.

(c) The sample period spans February 1984 to December 1997 except in the following cases where data are unavailable in the early months: Colombia, Malaysia, Nigeria, Pakistan, Philippines, Taiwan, Venezuela (all from February 1985) and Korea (from April 1985).

(d) * indicates significance at the $10 / 5$ percent level. 
Table 5B

\section{Developed Stock Markets - International Market Model February 1984 to December 1997}

$$
\mathrm{R}_{\mathrm{it}}=?{ }_{\mathrm{i}}+?{ }_{\mathrm{i}} \mathrm{R}_{\mathrm{wt}}+\mathrm{r}_{\mathrm{it}} \quad \ldots(1)
$$

\begin{tabular}{|c|c|c|c|c|c|c|}
\hline & \multicolumn{3}{|c|}{ MSCI World Index } & \multicolumn{3}{|c|}{ MSCI USA Index } \\
\hline Country & $?_{\mathrm{i}}$ & $?_{\mathrm{i}}$ & $\begin{array}{c}\text { Adjusted } \\
\mathrm{R}^{2}\end{array}$ & $?_{\mathrm{i}}$ & $?_{\mathrm{i}}$ & Adjusted $\mathrm{R}^{2}$ \\
\hline \multirow[t]{2}{*}{ Australia } & -0.002 & $0.956^{*}$ & 0.265 & -0.002 & $0.861^{*}$ & 0.223 \\
\hline & $(-0.30)$ & $(3.22)$ & & $(-0.31)$ & $(2.73)$ & \\
\hline \multirow[t]{2}{*}{ Austria } & 0.006 & $0.554 *$ & 0.094 & 0.009 & 0.241 & 0.014 \\
\hline & $(0.93)$ & $(3.13)$ & & $(1.42)$ & $(1.61)$ & \\
\hline \multirow[t]{2}{*}{ Belgium } & $0.007 *$ & $0.862 *$ & 0.452 & $0.008^{*}$ & $0.613^{*}$ & 0.235 \\
\hline & $(2.25)$ & $(9.89)$ & & $(2.28)$ & $(6.36)$ & \\
\hline \multirow[t]{2}{*}{ Canada } & -0.001 & $0.737 *$ & 0.449 & -0.003 & $0.807^{*}$ & 0.562 \\
\hline & $(-0.29)$ & $(7.32)$ & & $(-1.27)$ & $(12.04)$ & \\
\hline \multirow[t]{2}{*}{ Denmark } & 0.003 & $0.691 *$ & 0.259 & 0.005 & $0.434^{*}$ & 0.103 \\
\hline & $(0.77)$ & $(7.62)$ & & $(1.28)$ & $(4.57)$ & \\
\hline \multirow[t]{2}{*}{ France } & 0.002 & $1.023^{*}$ & 0.473 & 0.004 & $0.727^{*}$ & 0.246 \\
\hline & $(0.57)$ & (13.31) & & $(1.05)$ & $(7.70)$ & \\
\hline \multirow[t]{2}{*}{ Germany } & 0.003 & $0.878^{*}$ & 0.333 & 0.005 & $0.592^{*}$ & 0.154 \\
\hline & $(0.65)$ & $(6.98)$ & & (1.08) & $(4.46)$ & \\
\hline \multirow[t]{2}{*}{ Hong Kong } & 0.003 & $1.165^{*}$ & 0.302 & 0.001 & $1.125^{*}$ & 0.293 \\
\hline & $(0.34)$ & $(4.18)$ & & $(0.16)$ & $(4.13)$ & \\
\hline \multirow[t]{2}{*}{ Italy } & 0.001 & $0.916^{*}$ & 0.257 & 0.005 & $0.511 *$ & 0.079 \\
\hline & $(0.22)$ & $(7.28)$ & & $(0.89)$ & $(3.91)$ & \\
\hline \multirow[t]{2}{*}{ Japan } & -0.009 & $1.369 *$ & 0.589 & 0.002 & $0.422^{*}$ & 0.053 \\
\hline & $(-1.88)$ & $(8.78)$ & & $(0.29)$ & $(3.39)$ & \\
\hline \multirow[t]{2}{*}{ Netherlands } & $0.006^{*}$ & $0.849^{*}$ & 0.595 & $0.007^{*}$ & $0.679 *$ & 0.394 \\
\hline & $(2.74)$ & $(11.93)$ & & $(2.66)$ & $(9.72)$ & \\
\hline \multirow[t]{2}{*}{ Norway } & -0.001 & $0.984 *$ & 0.320 & -0.001 & $0.864^{*}$ & 0.255 \\
\hline & $(-0.18)$ & $(6.31)$ & & $(-0.17)$ & $(5.61)$ & \\
\hline \multirow[t]{2}{*}{ Singapore } & -0.007 & $0.983^{*}$ & 0.297 & -0.008 & $0.955^{*}$ & 0.292 \\
\hline & $(-1.02)$ & $(3.75)$ & & $(-1.20)$ & $(3.72)$ & \\
\hline \multirow[t]{2}{*}{ Spain } & 0.005 & $1.076^{*}$ & 0.418 & $0.008^{*}$ & $0.696^{*}$ & 0.179 \\
\hline & $(1.27)$ & $(9.21)$ & & $(1.69)$ & $(5.51)$ & \\
\hline \multirow[t]{2}{*}{ Sweden } & 0.002 & $1.042 *$ & 0.416 & 0.004 & $0.730^{*}$ & 0.210 \\
\hline & $(0.498)$ & $(8.80)$ & & $(0.92)$ & $(5.65)$ & \\
\hline \multirow[t]{2}{*}{ Switzerland } & $0.006^{*}$ & $0.856^{*}$ & 0.455 & $0.007^{*}$ & $0.640^{*}$ & 0.263 \\
\hline & $(1.83)$ & $(11.49)$ & & $(1.99)$ & $(7.09)$ & \\
\hline \multirow[t]{2}{*}{ UK } & 0.002 & $1.033^{*}$ & 0.580 & 0.003 & $0.800^{*}$ & 0.360 \\
\hline & $(0.54)$ & $(15.58)$ & & $(0.85)$ & $(10.11)$ & \\
\hline \multirow[t]{2}{*}{ USA } & $0.004 *$ & $0.767^{*}$ & 0.563 & $\mathrm{n} / \mathrm{a}$ & $\mathrm{n} / \mathrm{a}$ & $\mathrm{n} / \mathrm{a}$ \\
\hline & $(1.65)$ & $(8.25)$ & & & & \\
\hline
\end{tabular}

Notes:

(a) Standard errors are corrected using the Newey and West (1987) procedure for both autocorrelation and heteroskedasticity of an unknown form.

(b) T-statistics appear in parentheses and are a test of the null hypothesis that the coefficient is equal to zero.

(c) * indicates significance at the 5 percent level. 
Table 6A

Emerging Stock Markets - Political Risk Model

December 1985 to December 1997

\author{
World: $\mathrm{R}_{\mathrm{it}}=?_{\mathrm{i}}+?_{\mathrm{i}} \mathrm{R}_{\mathrm{wt}}$ ?? ? $\mathrm{r}_{\mathrm{it}} \quad \ldots(1)$ \\ Local: $\mathrm{r}_{\mathrm{it}}=?_{\mathrm{i}}+?{ }_{\mathrm{i}} \mathrm{FX} \mathrm{X}_{\mathrm{it}}$ ?? ? ${ }_{\mathrm{i}} \mathrm{DY} \mathrm{it}_{\mathrm{it}}$ ?? ?? ${ }_{\mathrm{i}}$ ?? ${ }_{\mathrm{rit}}+?_{\mathrm{i}} \mathrm{PR}_{\mathrm{it}}+?_{\mathrm{it}} \ldots$ (4) \\ where \\ $\mathbf{r}_{i t}$ is the residual returns from the world regression shown above (ie. of the \\ country return against the world market return), \\ $?{ }^{?}$ rit is computed by taking the absolute value of $\mathbf{r}_{\text {it }}$ multiplying this value by \\ the square root of (?/2), and then squaring the obtained value.
}

\begin{tabular}{|c|c|c|c|c|c|c|}
\hline Country & $?_{\mathrm{i}}$ & $?{ }_{\mathrm{i}} ?$ & $?_{\mathrm{i}}$ & $?_{\mathrm{i}}$ & $? ?$ & Adjusted $\mathrm{R}^{2}$ \\
\hline \multirow[t]{2}{*}{ Argentina } & 0.078 & -0.046 & -0.016 & 0.042 & -0.0011 & 0.01 \\
\hline & $(0.59)$ & $(-1.13)$ & $(-0.94)$ & $(0.59)$ & $(-0.56)$ & \\
\hline \multirow[t]{2}{*}{ Brazil } & 0.505 & -0.060 & -0.013 & $-0.492^{*}$ & -0.0072 & 0.06 \\
\hline & $(1.07)$ & $(-0.62)$ & $(-1.07)$ & $(-3.54)$ & $(-1.00)$ & \\
\hline \multirow[t]{2}{*}{ Chile } & $0.127 *$ & $1.713^{*}$ & $-0.377 *$ & 0.484 & $-0.0019^{*}$ & 0.48 \\
\hline & $(4.17)$ & $(5.23)$ & $(-9.92)$ & $(1.09)$ & $(-4.20)$ & \\
\hline \multirow[t]{2}{*}{ Colombia } & -0.033 & 0.185 & $-0.533^{*}$ & $0.878^{*}$ & 0.0004 & 0.67 \\
\hline & $(-0.60)$ & $(0.84)$ & $(-13.13)$ & $(4.22)$ & $(0.42)$ & \\
\hline \multirow[t]{2}{*}{ Greece } & 0.016 & 0.031 & $-0.065^{*}$ & $0.837^{*}$ & -0.0043 & 0.15 \\
\hline & $(0.19)$ & $(0.08)$ & $(-2.68)$ & $(4.37)$ & $(-0.34)$ & \\
\hline \multirow[t]{2}{*}{ India } & 0.007 & -0.126 & $-0.327 *$ & 0.397 & -0.002 & 0.31 \\
\hline & $(0.17)$ & $(-0.52)$ & $(-7.74)$ & $(1.27)$ & $(-0.21)$ & \\
\hline \multirow[t]{2}{*}{ Jordan } & -0.007 & -0.342 & -0.007 & 0.771 & 0.0013 & 0.01 \\
\hline & $(-0.48)$ & $(-1.92)$ & $(-0.55)$ & $(1.07)$ & $(0.50)$ & \\
\hline \multirow[t]{2}{*}{ Korea } & $0.133^{*}$ & $-1.264 *$ & -0.001 & 0.194 & $-0.0018^{*}$ & 0.30 \\
\hline & $(2.37)$ & $(-4.85)$ & $(-0.35)$ & $(0.55)$ & $(-2.35)$ & \\
\hline \multirow[t]{2}{*}{ Malaysia } & $0.113^{*}$ & $1.460^{*}$ & $-0.286^{*}$ & $-0.631 *$ & $-0.0014^{*}$ & 0.47 \\
\hline & $(2.25)$ & $(4.80)$ & $(-7.48)$ & $(-2.25)$ & $(-1.96)$ & \\
\hline \multirow[t]{2}{*}{ Mexico } & 0.238 & $-0.488^{*}$ & $-0.243^{*}$ & $-0.527 *$ & -0.0031 & 0.51 \\
\hline & $(1.41)$ & $(-3.50)$ & $(-5.57)$ & $(-6.66)$ & $(-1.26)$ & \\
\hline \multirow[t]{2}{*}{ Nigeria } & -0.143 & $0.796^{*}$ & -0.057 & $-0.383^{*}$ & 0.0036 & 0.51 \\
\hline & $(-1.48)$ & $(5.66)$ & $(-0.10)$ & $(-8.24)$ & $(1.81)$ & \\
\hline \multirow[t]{2}{*}{ Pakistan } & 0.031 & $-0.629 *$ & $-0.349 *$ & $1.137 *$ & -0.0008 & 0.40 \\
\hline & $(1.34)$ & $(-2.09)$ & $(-7.60)$ & $(4.32)$ & $(-1.64)$ & \\
\hline \multirow[t]{2}{*}{ Philippines } & $0.066^{*}$ & $1.248^{*}$ & $-0.262 *$ & 0.421 & $-0.0013 *$ & 0.36 \\
\hline & $(2.05)$ & $(3.29)$ & $(-7.35)$ & $(1.82)$ & $(-2.13)$ & \\
\hline \multirow[t]{2}{*}{ Thailand } & $0.262^{*}$ & -0.064 & $-0.113^{*}$ & $-0.854^{*}$ & $-0.0039 *$ & 0.24 \\
\hline & $(3.23)$ & $(-0.22)$ & $(-3.92)$ & $(-2.95)$ & $(-3.02)$ & \\
\hline \multirow[t]{2}{*}{ Venezuela } & -0.128 & $-0.326^{*}$ & $-0.376^{*}$ & $-0.601^{*}$ & 0.0022 & 0.32 \\
\hline & $(-0.66)$ & $(2.67)$ & $(-6.95)$ & $(-4.18)$ & $(0.74)$ & \\
\hline \multirow[t]{2}{*}{ Zimbabwe } & 0.061 & $-0.697 *$ & $-0.244 *$ & $-1.045^{*}$ & -0.0007 & 0.43 \\
\hline & $(1.11)$ & $(-3.83)$ & $(-5.70)$ & $(-6.14)$ & $(-0.69)$ & \\
\hline
\end{tabular}

Notes:

(a) Standard errors are corrected using the Cochrane-Orcutt two-stage procedure.

(b) T-statistics appear in parentheses and are a test of the null hypothesis that the coefficient is equal to zero.

(c) * indicates significance at the 5 percent level.

(d) Taiwan is omitted due to missing data on the exchange rate variable. 
Table 6B

\section{Developed Stock Markets - Political Risk Model December 1985 to December 1997}

$$
\text { World: } \mathrm{R}_{\mathrm{it}}=?{ }_{\mathrm{i}}+?{ }_{\mathrm{i}} \mathrm{R}_{\mathrm{wt}} ? ? ? \mathrm{r}_{\mathrm{it}} \quad \ldots(1)
$$

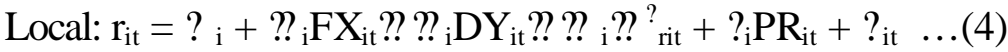

where

$\mathbf{r}_{\mathrm{it}}$ is the residual returns from the world regression shown above (ie. of the country return against the world market return),

$?{ }^{?}$ rit is computed by taking the absolute value of $\mathbf{r}_{\text {it }}$ multiplying this value by the square root of (?/2), and then squaring the obtained value.

\begin{tabular}{|c|c|c|c|c|c|c|}
\hline Country & $?_{\mathrm{i}}$ & $? ?_{\mathrm{i}} ?$ & $?_{\mathrm{i}}$ & $?_{\mathrm{i}}$ & $? ? ?_{\mathrm{i}}$ ? & Adjusted $\mathrm{R}^{2}$ \\
\hline \multirow[t]{2}{*}{ Australia } & 0.098 & $0.954 *$ & $-0.575^{*}$ & 0.198 & -0.0012 & 0.64 \\
\hline & $(1.50)$ & $(6.60)$ & $(-10.09)$ & $(1.01)$ & $(-1.51)$ & \\
\hline \multirow[t]{2}{*}{ Austria } & 0.078 & 0.268 & $-0.599 *$ & $0.826^{*}$ & -0.0010 & 0.54 \\
\hline & $(0.72)$ & $(1.91)$ & $(-12.63)$ & $(2.94)$ & $(-0.76)$ & \\
\hline \multirow[t]{2}{*}{ Belgium } & 0.056 & $0.331^{*}$ & $-0.222 *$ & $2.528^{*}$ & -0.0008 & 0.38 \\
\hline & $(0.81)$ & $(3.73)$ & $(-5.19)$ & $(5.75)$ & $(-0.92)$ & \\
\hline \multirow[t]{2}{*}{ Canada } & 0.021 & $0.766^{*}$ & $-0.415^{*}$ & -0.918 & -0.0003 & 0.47 \\
\hline & $(0.92)$ & $(3.72)$ & $(-8.18)$ & $(-1.13)$ & $(-0.89)$ & \\
\hline \multirow[t]{2}{*}{ Denmark } & 0.097 & $0.406^{*}$ & $-0.280 *$ & 0.110 & -0.0012 & 0.25 \\
\hline & $(0.77)$ & $(3.18)$ & $(-6.76)$ & $(0.17)$ & $(-0.78)$ & \\
\hline \multirow[t]{2}{*}{ France } & $-0.187^{*}$ & 0.108 & $-0.379 *$ & -0.819 & 0.0024 & 0.28 \\
\hline & $(-1.67)$ & $(0.98)$ & $(-7.25)$ & $(-1.74)$ & $(1.69)$ & \\
\hline \multirow[t]{2}{*}{ Germany } & -0.090 & $0.308^{*}$ & $-0.531^{*}$ & -0.677 & 0.0011 & 0.42 \\
\hline & $(-1.43)$ & $(2.46)$ & $(-9.87)$ & $(-1.59)$ & $(1.43)$ & \\
\hline \multirow[t]{2}{*}{ Hong Kong } & 0.056 & 0.276 & $-0.625^{*}$ & $0.751^{*}$ & -0.0009 & 0.64 \\
\hline & (1.66) & $(1.19)$ & $(-14.17)$ & $(3.31)$ & $(-1.79)$ & \\
\hline \multirow[t]{2}{*}{ Italy } & -0.087 & $0.438^{*}$ & $-0.605^{*}$ & 0.640 & 0.0011 & 0.54 \\
\hline & $(-1.67)$ & (3.18) & $(-12.30)$ & $(1.93)$ & $(1.61)$ & \\
\hline \multirow[t]{2}{*}{ Japan } & -0.025 & $0.546^{*}$ & $-0.199 *$ & $1.983^{*}$ & 0.0002 & 0.25 \\
\hline & $(-0.43)$ & $(5.02)$ & $(-4.46)$ & (3.99) & $(0.29)$ & \\
\hline \multirow[t]{2}{*}{ Netherlands } & 0.010 & 0.115 & $-0.190 *$ & -0.203 & -0.0001 & 0.11 \\
\hline & $(0.19)$ & $(1.40)$ & $(-4.31)$ & $(-0.17)$ & $(-0.21)$ & \\
\hline \multirow[t]{2}{*}{ Norway } & 0.169 & 0.195 & $-0.266^{*}$ & -1.084 & -0.0019 & 0.28 \\
\hline & $(1.24)$ & $(1.08)$ & $(-6.34)$ & $(1.94)$ & $(-1.19)$ & \\
\hline \multirow[t]{2}{*}{ Singapore } & $0.180^{*}$ & 0.140 & $-0.448^{*}$ & -0.140 & $-0.0022 *$ & 0.44 \\
\hline & $(1.96)$ & $(0.37)$ & $(-8.82)$ & $(-0.54)$ & $(-1.96)$ & \\
\hline \multirow[t]{2}{*}{ Spain } & 0.0086 & 0.135 & $-0.383^{*}$ & 0.449 & -0.0002 & 0.30 \\
\hline & $(0.13)$ & $(1.67)$ & $(-8.16)$ & $(0.83)$ & $(-0.20)$ & \\
\hline \multirow[t]{2}{*}{ Sweden } & -0.039 & 0.133 & $-0.258^{*}$ & $-1.697^{*}$ & 0.0005 & 0.30 \\
\hline & $(-0.56)$ & $(0.97)$ & $(-6.54)$ & (3.69) & $(0.66)$ & \\
\hline \multirow[t]{2}{*}{ Switzerland } & 0.051 & $0.320 *$ & $-0.300 *$ & 0.527 & -0.0006 & 0.23 \\
\hline & $(0.84)$ & $(3.50)$ & $(-6.37)$ & $(0.68)$ & $(-0.90)$ & \\
\hline \multirow[t]{2}{*}{ UK } & -0.008 & $0.378^{*}$ & $-0.268^{*}$ & 0.953 & 0.0001 & 0.24 \\
\hline & $(-0.16)$ & $(4.21)$ & $(-6.17)$ & $(1.06)$ & $(0.11)$ & \\
\hline \multirow[t]{2}{*}{ USA } & -0.022 & $0.381^{*}$ & $-0.416^{*}$ & 0.433 & 0.0002 & 0.50 \\
\hline & $(-0.53)$ & $(4.87)$ & $(-9.98)$ & $(0.52)$ & $(0.47)$ & \\
\hline
\end{tabular}

Notes:

(a) Standard errors are corrected using the Cochrane-Orcutt two-stage procedure.

(b) T-statistics appear in parentheses and are a test of the null hypothesis that the coefficient is equal to zero.

(c) * indicates significance at the 5 percent level. 
Table 7

\section{Comparison of Alternative ICRG Political Risk Measures in the Political Risk Model \\ December 1985 to December 1997}

$$
\text { World: } \mathrm{R}_{\mathrm{it}}=?{ }_{\mathrm{i}}+?{ }_{\mathrm{i}} \mathrm{R}_{\mathrm{wt}} ? ? ? \mathrm{r}_{\mathrm{it}} \quad \ldots(1)
$$

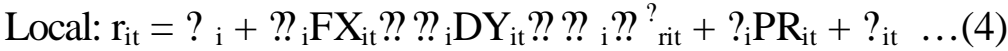

where

$\mathbf{r}_{i t}$ is the residual returns from the world regression shown above (ie. of the country return against the world market return),

$?{ }^{?}$ rit is computed by taking the absolute value of $\mathbf{r}_{\text {it }}$ multiplying this value by the square root of (?/2), and then squaring the obtained value.

\begin{tabular}{|c|c|c|c|c|}
\hline Country & Financial Risk & Economic Risk & Political Risk & Composite Risk \\
\hline \multirow[t]{2}{*}{ Argentina } & -0.0007 & -0.0015 & -0.0011 & -0.0008 \\
\hline & $(-0.45)$ & $(-0.78)$ & $(-0.56)$ & $(-0.62)$ \\
\hline \multirow[t]{2}{*}{ Brazil } & 0.0054 & 0.0001 & -0.0072 & 0.0016 \\
\hline & (1.49) & $(0.05)$ & $(-1.00)$ & $(0.45)$ \\
\hline \multirow[t]{2}{*}{ Chile } & $-0.0028 *$ & $-0.0036^{*}$ & $-0.0019 *$ & $-0.0019 *$ \\
\hline & $(-3.11)$ & $(-4.73)$ & $(-4.20)$ & $(-4.22)$ \\
\hline \multirow[t]{2}{*}{ Colombia } & -0.0011 & -0.0027 & 0.0004 & -0.0007 \\
\hline & $(-1.33)$ & $(-1.70)$ & $(0.42)$ & $(-0.84)$ \\
\hline \multirow[t]{2}{*}{ Greece } & -0.0013 & 0.0005 & -0.0043 & -0.0002 \\
\hline & $(-0.55)$ & $(0.15)$ & $(-0.34)$ & $(-0.17)$ \\
\hline \multirow[t]{2}{*}{ India } & -0.0007 & -0.0005 & -0.002 & -0.0003 \\
\hline & $(-0.48)$ & $(-0.23)$ & $(-0.21)$ & $(-0.36)$ \\
\hline \multirow[t]{2}{*}{ Jordan } & 0.0002 & 0.0003 & 0.0013 & 0.0001 \\
\hline & $(0.39)$ & $(0.22)$ & $(0.50)$ & $(0.47)$ \\
\hline \multirow[t]{2}{*}{ Korea } & -0.0011 & -0.0059 & $-0.0018^{*}$ & $-0.0021 *$ \\
\hline & $(-0.86)$ & $(-1.97)$ & $(-2.35)$ & $(-2.12)$ \\
\hline \multirow[t]{2}{*}{ Malaysia } & -0.0004 & -0.0017 & $-0.0014 *$ & -0.0009 \\
\hline & $(-0.53)$ & $(-0.70)$ & $(-1.96)$ & $(-1.28)$ \\
\hline \multirow[t]{2}{*}{ Mexico } & $-0.0036^{*}$ & $-0.0087 *$ & -0.0031 & $-0.0040 *$ \\
\hline & $(-2.98)$ & $(-3.41)$ & $(-1.26)$ & $(-2.95)$ \\
\hline \multirow[t]{2}{*}{ Nigeria } & 0.0008 & -0.0018 & 0.0036 & 0.0012 \\
\hline & $(0.46)$ & $(-0.76)$ & $(1.81)$ & $(0.69)$ \\
\hline \multirow[t]{2}{*}{ Pakistan } & -0.0019 & 0.0051 & -0.0008 & -0.0013 \\
\hline & $(-1.93)$ & $(1.24)$ & $(-1.64)$ & $(-1.74)$ \\
\hline \multirow[t]{2}{*}{ Philippines } & $-0.0022^{*}$ & $-0.0044^{*}$ & $-0.0013^{*}$ & $-0.0015^{*}$ \\
\hline & $(-2.23)$ & $(-2.32)$ & $(-2.13)$ & $(-2.24)$ \\
\hline \multirow[t]{2}{*}{ Thailand } & -0.0013 & -0.0055 & $-0.0039 *$ & $-0.0030 *$ \\
\hline & $(-0.79)$ & $(-1.54)$ & $(-3.02)$ & $(-2.20)$ \\
\hline \multirow[t]{2}{*}{ Venezuela } & 0.0006 & 0.0012 & 0.0022 & 0.0013 \\
\hline & $(0.28)$ & $(0.43)$ & $(0.74)$ & $(0.58)$ \\
\hline \multirow[t]{2}{*}{ Zimbabwe } & 0.0022 & 0.0039 & -0.0007 & 0.0003 \\
\hline & $(0.85)$ & $(1.61)$ & $(-0.69)$ & $(0.21)$ \\
\hline
\end{tabular}

Notes:

(a) Standard errors are corrected using the Cochrane-Orcutt two-stage procedure.

(b) T-statistics appear in parentheses and are a test of the null hypothesis that the coefficient is equal to zero.

(c) * indicates significance at the 5 percent level. 
Table 8

\title{
Aggregate Portfolio Tests of the Political Risk Model Using Pooled Regression December 1985 to December 1997
}

\author{
World: $\mathrm{R}_{\mathrm{t}}=?+? \mathrm{R}_{\mathrm{wt}} ? ? \mathrm{r}_{\mathrm{t}}$ \\ Local: $\mathrm{r}_{\mathrm{t}}=$ ? + ?? $\mathrm{FX}_{\mathrm{t}}$ ?? ? DY $\mathrm{t}_{\mathrm{t}}$ ?? ? ? ${ }_{\mathrm{rt}}+\mathrm{PR}_{\mathrm{t}}+?_{\mathrm{t}}$
}

where

$\mathbf{r}_{\mathbf{t}}$ is the pooled residual returns from the world regression shown above (ie. of the country return against the world market return),

$?{ }^{?}{ }_{\mathbf{r t}}$ is computed by taking the absolute value of $\mathbf{r}_{\mathbf{t}}$ multiplying this value by the square root of (?/2), and then squaring the obtained value.

\begin{tabular}{|c|c|c|c|c|c|c|c|}
\hline & ICRG measure & $?$ & $? ?$ & $? ?$ & $?$ & $?$ & Adj. $\mathrm{R}^{2}$ \\
\hline \multirow{2}{*}{$\begin{array}{l}\text { Emerging } \\
\text { markets }\end{array}$} & Political Risk & $0.038^{*}$ & -0.022 & $-0.011 *$ & $-0.325^{*}$ & $-0.00051 *$ & 0.079 \\
\hline & & $(2.67)$ & $(-1.10)$ & $(-3.70)$ & $(-12.88)$ & $(-2.17)$ & \\
\hline \multirow{6}{*}{ (16 markets) } & Economic Risk & $0.058^{*}$ & -0.032 & $-0.019 *$ & $-0.338 *$ & $-0.00154 *$ & 0.082 \\
\hline & & $(3.80)$ & $(-1.61)$ & $(-3.88)$ & $(-13.25)$ & $(-3.35)$ & \\
\hline & Financial Risk & $0.027 *$ & -0.024 & $-0.011 *$ & $-0.330^{*}$ & -0.00058 & 0.079 \\
\hline & & $(2.42)$ & $(-1.25)$ & $(-3.75)$ & $(-13.01)$ & $(-1.78)$ & \\
\hline & Composite Risk & $0.048^{*}$ & -0.025 & $-0.011 *$ & $-0.330^{*}$ & $-0.00064 *$ & 0.081 \\
\hline & & $(3.08)$ & $(-1.28)$ & $(-3.74)$ & $(-13.05)$ & $(-2.63)$ & \\
\hline \multirow{2}{*}{$\begin{array}{l}\text { Developed } \\
\text { markets }\end{array}$} & Political Risk & 0.009 & $0.315^{*}$ & $-0.409^{*}$ & 0.010 & -0.00012 & 0.365 \\
\hline & & $(1.03)$ & $(10.44)$ & $(-36.89)$ & $(0.14)$ & $(-1.15)$ & \\
\hline \multirow[t]{6}{*}{ (18 markets) } & Economic Risk & 0.016 & $0.315^{*}$ & $-0.409 *$ & 0.013 & -0.00044 & 0.366 \\
\hline & & $(1.66)$ & $(10.45)$ & $(-36.92)$ & $(0.17)$ & $(-1.76)$ & \\
\hline & Financial Risk & 0.001 & $0.315^{*}$ & $-0.409 *$ & 0.011 & -0.00005 & 0.365 \\
\hline & & $(0.17)$ & $(10.42)$ & $(-36.87)$ & $(0.14)$ & $(-0.30)$ & \\
\hline & Composite Risk & 0.012 & $0.315 *$ & $-0.409 *$ & 0.008 & -0.00016 & 0.366 \\
\hline & & $(1.19)$ & $(10.43)$ & $(-36.87)$ & $(0.10)$ & $(-1.29)$ & \\
\hline \multirow{2}{*}{$\begin{array}{l}\text { Combined } \\
\text { sample }\end{array}$} & Political Risk & $0.0294^{*}$ & -0.009 & $-0.016^{*}$ & $-0.329 *$ & $-0.0035^{*}$ & 0.071 \\
\hline & & $(4.19)$ & $(-0.61)$ & $(-6.76)$ & $(-17.44)$ & $(-3.65)$ & \\
\hline \multirow[t]{6}{*}{ (34 markets) } & Economic Risk & $0.046^{*}$ & -0.016 & $-0.016^{*}$ & $-0.339 *$ & $-0.0012^{*}$ & 0.073 \\
\hline & & $(5.37)$ & $(-1.14)$ & $(-6.95)$ & $(-17.79)$ & $(-4.92)$ & \\
\hline & Financial Risk & $0.0242 *$ & -0.011 & $-0.016^{*}$ & $-0.333^{*}$ & $-0.0005^{*}$ & 0.070 \\
\hline & & $(3.97)$ & $(-0.76)$ & $(-6.78)$ & $(-17.49)$ & $(-3.34)$ & \\
\hline & Composite Risk & $0.035^{*}$ & -0.011 & $-0.016^{*}$ & $-0.334 *$ & $-0.0004 *$ & 0.072 \\
\hline & & $(4.61)$ & $(-0.78)$ & $(-6.81)$ & $(-17.58)$ & $(-4.10)$ & \\
\hline
\end{tabular}

Notes:
(a) The ICRG measure indicates the ICRG index used to proxy for political risk $\left(\mathrm{PR}_{t}\right)$ in the regression.
(b) Standard errors are corrected using the Cochrane-Orcutt two-stage procedure.
(c) T-statistics appear in parentheses and are a test of the null hypothesis that the coefficient is equal to zero.
(d) * indicates significance at the 5 percent level. 
Table 9

\section{Political Risk Model Across Sub-Samples Using Pooled Regression December 1985 to December 1997}

Model - World: $\mathrm{R}_{\mathrm{t}}=?+? \mathrm{R}_{\mathrm{w}} ? ?$ ? $\mathrm{r}_{\mathrm{t}}$

Local: $\mathrm{r}_{\mathrm{t}}=$ ? + ?? $\mathrm{FX}_{\mathrm{t}}$ ?? ? DY ${ }_{\mathrm{t}}$ ?? ?? ? ${ }_{\mathrm{rt}}+\mathrm{PR}_{\mathrm{t}}+?_{\mathrm{t}}$

where

$\mathbf{r}_{\mathbf{t}}$ is the pooled residual returns from the world regression shown above (ie. of the country return against the world market return),

$?{ }^{?}{ }_{\mathbf{r t}}$ is computed by taking the absolute value of $\mathbf{r}_{\mathbf{t}}$ multiplying this value by the square root of (?/2), and then squaring the obtained value.

\begin{tabular}{|c|c|c|c|c|c|c|}
\hline $\begin{array}{c}\text { Emerging } \\
\text { markets }\end{array}$ & $?$ & $? ?$ & $? ?$ & $?$ & $?$ & ${\text { Adjusted } \mathrm{R}^{2}}$ \\
\hline $12 / 85-12 / 91$ & -0.007 & -0.022 & $-0.022^{*}$ & $-0.209^{*}$ & 0.00041 & 0.04 \\
\hline$(\mathrm{n}=73)$ & $(-0.37)$ & $(-0.98)$ & $(-3.66)$ & $(-5.90)$ & $(1.13)$ & \\
\hline & & & & & & \\
\hline $1 / 92-12 / 97$ & $0.074^{*}$ & -0.015 & $-0.007^{*}$ & $-0.508^{*}$ & $-0.00182^{*}$ & 0.17 \\
\hline$(\mathrm{n}=72)$ & $(3.74)$ & $(-0.30)$ & $(-2.27)$ & $(-14.65)$ & $(-3.11)$ & \\
\hline & & & & & & \\
\hline $\begin{array}{c}\text { Developed } \\
\text { markets }\end{array}$ & $?$ & $? ?$ & $? ?$ & $?$ & & Adjusted $\mathrm{R}^{2}$ \\
\hline $12 / 85-12 / 91$ & 0.011 & $0.253^{*}$ & $-0.419^{*}$ & -0.011 & -0.00013 & 0.38 \\
\hline$(\mathrm{n}=73)$ & $(0.98)$ & $(5.64)$ & $(-26.11)$ & $(-0.12)$ & $(-0.93)$ & \\
\hline & & & & & & \\
\hline $1 / 92-12 / 97$ & 0.003 & $0.377^{*}$ & $-0.395^{*}$ & 0.125 & -0.00006 & 0.35 \\
\hline$(\mathrm{n}=72)$ & $(0.25)$ & $(9.36)$ & $(-25.85)$ & $(0.84)$ & $(-0.42)$ & \\
\hline & & & & & & \\
\hline
\end{tabular}

Notes:

(a) Standard errors are corrected using the Cochrane-Orcutt two-stage procedure.

(b) T-statistics appear in parentheses and are a test of the null hypothesis that the coefficient is equal to zero.

(c) * indicates significance at the 5 percent level. 